\title{
Government OWNERSHIP OF BANKS, Institutions, AND FINANCIAL DEVELOPMENT*
}

\author{
Svetlana Andrianova,$^{\dagger}$ Panicos Demetriades,$\stackrel{\ddagger}{ }$ and Anja Shortland ${ }^{\S}$
}

This version: August 2, 2006

\begin{abstract}
Using a suitably modified locational model of banking, we examine the influence of institutions, such as deposit contract enforcement, in explaining the share of government owned banks in the banking system. We present cross-country evidence suggesting that institutional factors are relatively more important determinants of the share of state banks than political or historical ones. We argue that rather than privatizing or subsidizing state banks governments in developing countries should build institutions that foster the development of private banking.
\end{abstract}

KEYWORDS: Regulation, opportunistic banks, institutional quality

JEL: D82, G21, G28, K42

\footnotetext{
${ }^{*}$ We would like to thank an anonymous referee of this journal for helpful comments. We would also like to thank without implicating: Jagjit Chadha, Charles Goodhart, Roger Hartley, Theofanis Mamuneas, Steve Pudney, Tim Worrall, seminar participants at the Universities of Brunel, Cambridge, Cyprus, Keele, Leicester, Liverpool and Manchester, as well as participants of the Global Finance MMF workshop at Birmingham University, the MMF conference in Cambridge, and the 21st Symposium on Banking and Monetary Economics in Nice for stimulating discussions. Shortland would like to thank Peter Uimonen of the IMF for providing the IMF MONA database. Andrianova and Demetriades acknowledge financial support from the ESRC under the World Economy and Finance Programme (Award RES-156-25-0009).

${ }^{\dagger}$ Department of Economics, University of Leicester, University Road, Leicester, LE1 7RH, United Kingdom. Email: s.andrianova@le.ac.uk.

${ }^{\ddagger}$ Department of Economics, University of Leicester, University Road, Leicester LE1 7RH, United Kingdom. Email: pd28@le.ac.uk.

${ }^{\S}$ Department of Economics and Finance, Business School, Brunel University, Uxbridge, Middlesex UB8 3PH, United Kingdom. Email: Anja.Shortland@brunel.ac.uk
} 


\section{Introduction}

It is now widely accepted that well functioning financial systems can help promote economic growth, especially in middle income countries (Rioja and Valev 2004, Demetriades and Andrianova 2004). However, the policies that could advance financial development remain elusive for many developing countries. Importantly, financial liberalization, widely considered critical in delivering a more efficient and competitive banking system, has frequently been followed by financial instability, especially where institutions such as rule-of-law and regulation were weak (Demirgüç-Kunt and Detragiache 1999, Kaminsky and Reinhart 1999, Arestis and Demetriades 1999). Surprisingly, even though financial liberalization policies have been widely adopted, government ownership of banks remains prevalent in many countries (Barth, Caprio and Levine 2000). Could this stylized fact to some extent explain why financial development has not taken off in some countries, or, indeed why financial liberalization has been followed by financial instability? An important recent paper by La Porta, Lopez-de-Silanes and Shleifer (2002) suggests that this may indeed be the case. The authors report a number of cross-country correlations which suggest that the degree of government ownership in the banking system is negatively related to subsequent financial development and economic growth, and positively associated with financial instability. If these relationships are causal, as indeed is implied by the authors, then large-scale privatizations of banking systems around the world could generate enormous benefits in terms of both financial development and economic growth. ${ }^{1}$ However, if the relationships observed in the cross-country data reflect reverse causality or are driven by other factors, then it is essential to know what factors determine the presence of government owned banks and what the likely implications of their privatization might be.

A careful analysis of government ownership of banks needs to explain why state banks exist in the first place. Is it purely driven by political motives, as postulated by the "political view" of state banking, or is it a response to institutional deficiency ${ }^{2}$ Stylized facts, as well as empirical studies,

\footnotetext{
${ }^{1}$ The estimated effects in La Porta et al. (2002) are quite large: a 10 percentage points rise in the share of government ownership of banks reduces the growth rate by approximately $0.25 \%$ per annum.

${ }^{2}$ Stiglitz (2002), pp. 54-59 and 157-160, provides a vivid illustration of the risks associated with premature privatization in both developing and transition economies. See also Perotti (2001), who discusses the Russian experience.
} 
provide credence to both possibilities. For example, the evidence from Russia suggests that mistrust of banks by the general public means that most savings are not in the financial system and that $70 \%$ of retail bank deposits are controlled by Sberbank, the largest state savings bank. ${ }^{3}$ Additionally, the bi-variate cross country regressions reported in La Porta et al. (2002), suggest that government ownership of banks is negatively correlated with property rights protection and other institutional quality indicators, as well as with political rights or democracy. ${ }^{4}$

In order to advance our understanding of the determinants of the share of state (government owned) banks in the banking system, this paper offers a theoretical analysis of depositors' behavior, when they have a choice between private and state banks. We postulate a plausible trade-off between the two types of bank, the nature of which is affected by institutional quality. Specifically, while private banks are assumed to be more efficient than the government owned bank, some private banks are assumed to be opportunistic. Under weak institutional quality, the presence of opportunistic banks may create a preference for the less efficient but safer state bank among some depositors. The institutions which matter for this trade-off are those that could contain opportunistic behavior by banks (specifically, prudential regulation and supervision, contract enforcement, and more broadly, the rule of law); these kinds of institutions can play a fundamental role in protecting depositors' property rights. Another institution that could, in principle, protect depositors is deposit insurance. However, explicit deposit insurance is absent in many financially underdeveloped economies. Even where it exists, it is less than perfect. A recent World Bank survey of banking practices around the world (Barth, Caprio and Levine 2001) reveals that 32 out of the 83 countries studied in the empirical section of this paper did not have an explicit deposit insurance law. The uninsured sample includes some highly developed financial systems such as New Zealand, Australia and Singapore but mostly underdeveloped financial systems such as Rwanda, Russia, Gambia, Ghana, Burundi and Moldova. Of the 51 countries that had explicit deposit insurance six did not fully compensate depositors the last time a bank failed, 4 did not report whether they compensated depositors and 8 reported no bank failures. In most of the remaining 33 countries depositors in failed banks had to wait for long periods of time to get reim-

\footnotetext{
${ }^{3}$ CSI (Coalition of Service Industries) Background Paper on Russian Banking Services (22 May 2002).

${ }^{4}$ It should be noted, however, that the bi-variate nature of the regressions reported in Table III in La Porta et al. (2002) makes it impossible to establish which determinants of government ownership of banks are the statistically significant ones.
} 
bursed, sometimes more than a year. Our modeling of depositor compensation as both imperfect and uncertain concurs well with these facts.

Our argument is developed in a locational model of banking that allows us to examine both banks' and depositors' behavior. A novel feature of our model is that it contains two types of private banks: honest and opportunistic. ${ }^{5}$ The former type always honor their contracts with depositors (due to, perhaps, high reputational costs), while the latter choose whether to do so depending on the probability of deposit contract enforcement. To this set-up we also add a state bank that is assumed to be less efficient than private banks. Depositors are unable to distinguish between honest and opportunistic (private) banks, but know the probability of encountering each type and also know the probability of deposit compensation, should they end up with an opportunistic bank that breaches its deposit contracts. This set-up results in three different types of equilibria. A "low" equilibrium occurs when institutional quality is low, the proportion of opportunists is high, and no private bank would choose to enter. A "high" equilibrium occurs when institutional quality is sufficiently high and all private banks honor their deposit contracts. In the absence of subsidies to the government owned bank, this translates into all depositors placing their funds with private banks. And, finally, an "intermediate equilibrium", in which private banks and the state bank co-exist. We show that in the latter region the demand for state deposit contracts is greater when the enforcement probability is lower or the proportion of opportunistic banks is greater. We also show that when institutional quality is poor, nonexistence of the state bank leads to financial disintermediation. The model is enriched further by introducing an enforcement externality which may arise from fixed resources devoted to the enforcement of deposit contracts. This extension leads to multiple equilibria for a certain range of parameter values. The equilibrium is then determined by perceived institutional quality: even when institutional quality is relatively high, the economy may end up in the low or intermediate equilibrium if depositors believe that opportunistic banks would breach their deposit contracts.

\footnotetext{
${ }^{5}$ Gerschenkron (1962) provides the example of Russia in the 19the century where "...the standards of honesty in business were so disastrously low that no bank could have hoped to attract even such small capital funds as were available ..." (p. 19). Modern day examples of opportunistic behavior in private banking include the recent experience of transition economies with wildcat private banks. The Financial Times (6 June, 22 and 23 December of 1995, and 30 January 1996) documents a number of such episodes in the Baltic States. There are also examples from developed economies, which almost invariably reflect failures of prudential regulation, such as the case of BCCI, and the example of pension misselling in the UK, including the recent one of Equitable Life.
} 
In a further extension of the model, we show that the introduction of government subsidies for the state bank, which may reflect political considerations, can lead to a shrinking of the high equilibrium region. This is because subsidized state banks have an unfair advantage over private banks, in that they can offer more competitive deposit rates than private banks to some depositors, thus creating a positive demand for state deposit contracts even when institutional quality is high. In the medium range of institutional quality, this encourages opportunistic banks to breach their deposit contracts.

We test our theoretical predictions using cross-country data by regressing the share of assets in state controlled banks obtained from Barth et al. (2001) on a number of variables that are suggested by the theory. Specifically, we utilize a number of institutional quality indicators, including prudential regulation, rule of law and disclosure requirements. Additionally, we utilize a number of proxies to capture the possible influence of politically motivated subsidies, including a political orientation dummy, the share of government consumption in GDP and a variable that captures the presence of an IMF program. To check for robustness of our results to more general specifications, we repeat all the regressions by adding legal origin variables. These variables may reflect wider political or historical determinants of the share of state banks and, as such, are not captured by our theoretical model. We also carry out additional robustness checks using alternative dependent variables, which reflect different definitions of government ownership of banks. These checks bolster the empirical case further. They also provide additional insights into the extent of government ownership required for state banks to be perceived as good substitutes for weak institutions.

The paper is structured as follows. Section 2 presents the theoretical model and its predictions. Section 3 presents the data and empirical findings. Section 4 concludes by discussing some policy implications.

\section{Theory}

\section{$2.1 \quad$ Model}

Our starting point is the "circular city" model of product differentiation: by locating at a particular point in the product space, the bank chooses to offer a specific bundle of banking services, 
while otherwise identical depositors differ in their preferences over a mix of banking services. ${ }^{6}$ The bank chooses a specific bundle, rather than a continuum of bundles for all possible preferences, because the fixed costs of developing and researching all possible bundles are too large. The discrepancy between the bundle offered by the bank and that preferred by a given depositor is captured by the "distance" between the depositor and the bank, which leads to the depositor's utility loss (captured by a "transportation" cost) from not consuming his/her preferred bundle. This model is extended to incorporate a state bank together with the possibility of opportunistic behavior by private banks. ${ }^{7}$

Specifically, a single state bank and $n$ private banks compete for deposit contracts. The money collected from private depositors can be invested into a riskless technology with a constant rate of return $r$. The depositors are endowed with 1 unit of cash but do not have direct access to this technology: they have to transact (by striking a deposit contract) with a bank to earn a return on their cash holdings. There is a continuum of risk-neutral depositors who are uniformly distributed along a circle. Distribution density and the length of the circle are both unitary. A depositor incurs a positive transportation $\operatorname{cost} \alpha$ which is proportional to the distance between the depositor and the bank. ${ }^{8}$

The state bank is located in the center of the circle, reflecting the transition or development context that we have in mind. That is to say, it is assumed to have been in existence for some time, and, as a result, has a branch network and/or product range that appeals equally to all depositors. ${ }^{9}$ It therefore offers a net deposit rate of $r_{s}=r_{s}^{0}-\alpha /(2 \pi)>0$ to all depositors.

Private banks are located anywhere along the circle with bank $i$ offering deposit rate $r_{i}(i=$

\footnotetext{
${ }^{6}$ The "circular city" was originally developed by Salop (1979) to model monopolistic competition between firms. It was subsequently applied to banking (Freixas and Rochet 1997) as an analytically convenient way to model deposit contracts competition among banks which differ only in their fixed setup cost. We choose this model as our starting point because it allows us (i) to focus on savings mobilization - as opposed to the loan-making - function of banking, and (ii) to introduce into the model two new aspects: bank ownership and asymmetric information.

${ }^{7}$ Implicitly, each private bank has only one branch. It can be shown that allowing for multiple branches would not change the results, provided that the branches are not adjacent. See Freixas and Rochet (1997).

${ }^{8}$ The linear cost is not important; any convex cost function would lead to the same results (Tirole 1988, Freixas and Rochet 1997).

${ }^{9}$ This implies, in particular, a zero fixed cost of the state bank.
} 
FiguRE 1: Structure of the banking industry

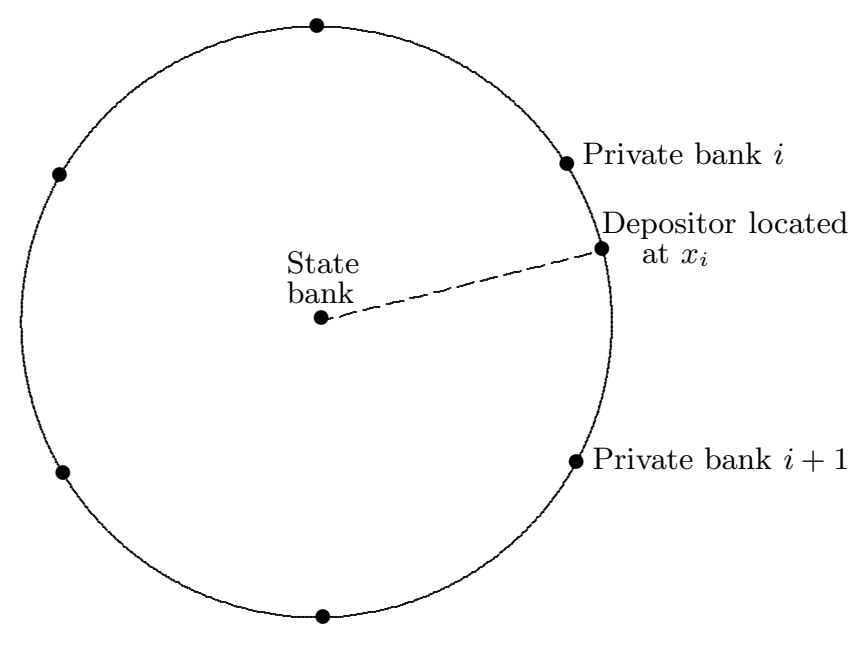

$1, \ldots, n)$. There are potentially many identical private banks that can enter the industry at a positive fixed cost, $F$. In this setup, therefore, each operating private bank competes with its two immediate neighbors, while the state bank is, in principle, able to compete with all private banks. The return from the state deposit contract is assumed to be certain: the state bank honors its deposit contracts without fail. This may be because the accountability of the public sector by means of various bureaucratic controls prevents the state bank from taking advantage of its depositors, albeit at the cost of lower efficiency compared to a private bank (see (A2) and further discussion below). The assumption that the state bank is honest refers only to how state banks deal with depositors. It does not rule out the possibility that the government imposes an inflation tax or that lending officers of the state bank are corrupt.

An operating private bank could be of either opportunistic type with probability $\gamma$ (with $0<$ $\gamma<1$ ), or of honest type with probability $1-\gamma$. The type of a bank is private information, while the value of $\gamma$ is common knowledge. ${ }^{10}$ An honest bank never fails to honor its deposit contract: at the end of the deposit contract it pays out the deposit rate specified in the contract, together with the initial deposit of 1 unit of cash. The distinction between "honest" and "opportunistic" banks captures dynamic reputational considerations which are not explicitly modeled in our static framework. A non-myopic, or "honest", bank's concern for the future forces it to honor all its

\footnotetext{
${ }^{10}$ For example, $\gamma$ may reflect the ease of entry into the banking industry.
} 
deposit contracts in expectation of continued custom by its existing depositors. In contrast, a myopic, or "opportunistic", bank has no concern for the future and may choose to seize any shortterm gainful opportunity even if it hurts its existing depositors. The gainful opportunity in the model is the breach of the deposit contract: the bank takes the money and runs, and therefore the depositor loses not just the promise of $r_{i}$ but also his initial deposit of 1 unit of cash. ${ }^{11}$ An opportunistic bank's choice between honoring and breaching its deposit contracts depends, however, on the quality of enforcement institutions. The latter are assumed to be such that a cheated depositor expects to get a payment of deposit compensation, $d>0$, from the offending bank with probability $\lambda$ (with $0<\lambda \leq 1$ ).

The timing of the game is as follows.

(1) Private banks decide whether to enter; $n$ banks enter.

(2) Private bank $i(i=1, \ldots, n)$ sets its deposit rate $r_{i}$.

(3) Each depositor chooses the bank in which to place the deposit of 1 monetary unit.

(4) Opportunistic banks choose whether to honor or breach their deposit contracts.

(5) If a contractual breach has occurred, the affected depositors seek compensation.

(6) Payoffs are realized.

Given the sequential nature of the game, the appropriate solution method is backward induction. Firstly, for a given strategy of opportunistic banks (namely, breach of or compliance with the deposit contract), depositors choose which bank to entrust with their deposit. Secondly, given the level of demand for its deposit contracts, each bank sets the deposit rate at the level which maximizes its profits. Finally, for a given level of demand and profit maximizing deposit rate, each private bank decides whether to enter. The benchmark case is analyzed in section 2.2 and then extended to include an enforcement externality in section 2.3 and a subsidy to the state bank in section 2.4. All proofs are contained in Appendix A.

\footnotetext{
${ }^{11}$ This assumption is based on bank "looting" strategies such as those explored in Akerlof, Romer, Hall and Mankiw (1993, pp. 1-73)
} 


\subsection{Benchmark case}

Let $q \in\{0,1\}$ represent an opportunistic bank's decision to honor its deposit contracts where the value of $q(q=1$ honor, or $q=0$ breach) is set by the bank to maximize its profits. As a shortcut, call $q$ the probability of compliance (or, $1-q$ the probability of breach). Consider the expected payoffs of the players (depositors and private banks). By going to a private bank $i$, a depositor located at distance $x_{i}$ expects to obtain:

$$
U_{i}^{p b}(q)=[1-\gamma(1-q)] \cdot\left(1+r_{i}\right)+\gamma(1-q) \cdot \lambda d-\alpha x_{i}
$$

where $\alpha x_{i}$ is the transportation (or transaction) cost. If the bank does not cheat (with probability $[1-\gamma(1-q)])$ the depositor gets the contractual rate $r_{i}$, in addition to the initial holding of 1 unit of cash. Otherwise (with probability $\gamma(1-q)$ ), the depositor loses his 1 unit of cash but expects the deposit compensation of $d$ with probability $\lambda$.

Any private bank at the end of the deposit contract has in its possession $1+r$ per depositor. An honest bank honors all of its deposit contracts by paying out $1+r_{i}$, and therefore retains as (per depositor) profit the difference between the rate $r$ determined by the investment technology and the rate $r_{i}$ it offers. An opportunistic bank, in contrast, pays out $1+r_{i}$ only if it honors its contract (with probability $q$ ), and additionally expects to lose $\lambda d$ per depositor if it cheats (with probability $1-q$ ). Because the deposit contract offered by a given bank is the same for all depositors, the opportunistic bank that decides to breach one of its deposit contracts will cheat all of its depositors. Denoting by $D_{i}$ the demand for bank $i(i=1, \ldots, n)$, the expected profit of an honest and opportunistic private bank, respectively, is therefore calculated as follows:

$$
\begin{aligned}
V^{1-\gamma} & =\left(r-r_{i}\right) \cdot D_{i}, \\
V^{\gamma}(q, \lambda, d) & =\left[(1+r)-q\left(1+r_{i}\right)-(1-q) \lambda d\right] \cdot D_{i} .
\end{aligned}
$$

The expected payoffs from a deposit contract with a state bank are

$$
U^{s b}=1+r_{s}
$$

to any depositor, because every depositor is one radius away from the state bank (with $r_{s}=$ $\left.r_{s}^{0}-\alpha /(2 \pi)\right)$, and $V^{s}=\left(r-r_{s}^{0}\right) \cdot D_{s}$ to the state bank. To simplify the exposition further, the analysis of the model utilizes the following: 
Under (A1), ${ }^{12}$ the expected payoffs (1) and (3) above simplify to the following:

$$
\begin{aligned}
U_{i}^{p b}(q) & =[1-\gamma(1-q)] \cdot\left(1+r_{i}\right)+\gamma(1-q) \cdot \lambda(1+r)-\alpha x_{i}, \\
V^{\gamma}\left(r_{i}, q, \lambda\right) & =\left[q\left(r-r_{i}\right)+(1-q)(1+r)(1-\lambda)\right] \cdot D_{i} .
\end{aligned}
$$

\section{Assumption 2}

$$
r_{s} \leq r-3 / 2 \cdot \sqrt{\alpha F}
$$

(A2) states that in the absence of enforcement problems, private banking is more efficient than state banking: the highest deposit rate that the state bank could offer is the rate which makes the marginal depositor located at distance $x_{i}=1 /(2 n)$ from private bank $i$ just indifferent between private bank $i$ and the state bank. In the case of such a tie, we assume that the depositor goes to private bank $i$. Of course, any depositor located at $x_{i}<1 /(2 n)$ will strictly prefer (the nearest) bank $i$ over the state bank. The justification of this assumption arises from the transition and/or development context we have in mind here: the state bank, which under (A2) faces a horizontal average cost curve, pre-dates any private bank in a sense that the fixed cost of setting up the state bank is long bygone (making the state bank's fixed cost now effectively zero). In contrast, any private bank which contemplates entry faces a rectangular hyperbolic average cost curve because it has to bear a positive fixed set-up cost.

Three types of pure strategy equilibria are possible in this game (see Table 1 below): "high"

TABLE 1: Description of equilibria.

\begin{tabular}{lccll}
\hline & & & \\
Equilibrium & & & \multicolumn{2}{c}{ Type of banking demanded } \\
\hline High & (HE) & $q=1$ & private only & $D_{i}=1 / n$ \\
Intermediate & (IE) & $q=0$ & state and private & $0<D_{i}<1 / n$ \\
Low & (LE) & $q=0$ & state only & $D_{i}=0$ \\
\hline
\end{tabular}

equilibrium (HE) where all banking is undertaken by private banks, "intermediate" equilibrium

\footnotetext{
${ }^{12}$ Notice that this assumption is biased against the state bank's deposit contracts, as harsher punishment of opportunistic behavior will provide greater incentive for private banks to honor their deposit contracts.
} 
(IE) with both the state and private banks enjoying positive demand for deposit contracts, and "low" equilibrium (LE) where only the state bank is operational. To ease the exposition of our results, we introduce the following additional notation:

$$
\begin{gathered}
\bar{\lambda} \equiv 1-\frac{\sqrt{\alpha F}}{1+r}, \quad \tilde{\lambda}_{1} \equiv 1-\frac{r-r_{s}}{(2-\gamma)(1+r)}, \quad \tilde{\lambda}_{2} \equiv 1-\frac{r-r_{s}}{\gamma(1+r)}, \\
\tilde{n} \equiv \frac{r(1-\gamma)-r_{s}-\gamma(1-\lambda(1+r))}{2 F(1-\gamma)} .
\end{gathered}
$$

These cut-offs arise from the analysis of (i) an opportunistic bank's decision to comply with (if $\lambda \geq \bar{\lambda}$ ) or breach (if $\lambda<\tilde{\lambda}_{1}$ ) all its deposit contracts; (ii) an honest bank's decision to enter the industry, given the low demand in the presence of breaching opportunistic banks (if $\lambda>\tilde{\lambda}_{2}$ ); and (iii) demand for private bank deposits in IE being necessarily smaller than that in HE (if $n<\tilde{n}$ ).

Proposition 1 Assume (A1) and (A2). A unique (pure strategy) equilibrium exists and it is of type:

(i) HE, if $\lambda \geq \bar{\lambda}$. Then $r_{i}=r-\sqrt{\alpha F}, D_{i}=\sqrt{F / \alpha}$, and $n=\sqrt{\alpha / F}(i=1, \ldots, n)$;

(ii) IE, if $\tilde{\lambda}_{2} \leq \lambda<\min \left\{\bar{\lambda}, \tilde{\lambda}_{1}\right\}$. Then $r_{i}=\left[r(1-\gamma)+r_{s}+\gamma(1-\lambda(1+r))\right] /[2(1-\gamma)]$, $D_{i}=2 \cdot\left[r(1-\gamma)-r_{s}-\gamma(1-\lambda(1+r))\right] / \alpha$ and $n<\tilde{n}(i=1, \ldots, n)$;

(iii) $L E$, if $\lambda<\tilde{\lambda}_{2}$. Then $D_{i}=0(i=1, \ldots, n)$, and $n=0$.

Note that the equilibria derived in the proposition are all pooling. It can be easily established that a separating equilibrium (in the non-trivial case of IE) does not arise in this game. This is because any positive demand for private banks' deposit contracts, which leads to ex post positive profits, will stimulate entry by both types of banks, given that the fixed entry cost is the same for either type of bank, while an opportunistic bank can costlessly mimic an honest bank's deposit rate offer.

Figure 2 illustrates Proposition 1. HE exists when the enforcement of deposit contracts is sufficiently good. A high enough probability of penalty under the enforced deposit contract forces every opportunistic private bank to behave honestly. Consequently, all depositors prefer private banking over state banking, with the marginal depositor being indifferent between the two nearest private banks. The equilibrium demand for private banking (as determined by the location of the 
marginal depositor) enters the profit function of the private bank which sets its deposit rate at the profit-maximizing level. All banks being identical in this equilibrium, the symmetric problem has the unique solution specified by Proposition 1(i). Assumption (A2) is necessary to ensure that the marginal depositor gets as large a payoff from private banking as he would from state banking. ${ }^{13}$

FigURE 2: Equilibria in the benchmark case (assuming $r_{s}=r-3 / 2 \cdot \sqrt{\alpha F}$ ).

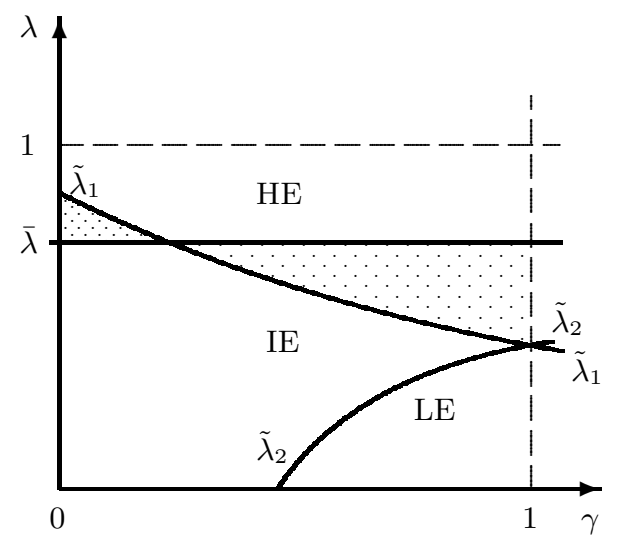

In both IE and LE, all opportunistic banks cheat because the enforcement probability is relatively low. The location of the marginal depositor in either equilibrium determines the profits of the honest bank which, should it enter the industry, will be setting its deposit rate at the profitmaximizing level. This level is feasible - gives a positive ex post profit - when the proportion of opportunistic banks is relatively low while the probability of deposit contract enforcement is relatively high. In such a case, honest banks enter, and the expected payoff from private banking is as large as that from the state bank, provided that the depositor is located close enough to a private bank. If, in contrast, the proportion of opportunistic banks is relatively large while the enforcement probability is relatively small, the rate that maximizes an honest bank's profit, given the demand, has to be set at too high a level for the honest bank to be able to make a positive (ex post) profit. Hence, the honest banks do not enter, and the foreseen absence of the honest banks in combination with the certainty of breach by an opportunistic bank, makes state deposit

\footnotetext{
${ }^{13} \mathrm{HE}$ is therefore a standard solution of the "circular city" model, except for the additional condition on the value of the enforcement probability (Salop 1979, Freixas and Rochet 1997).
} 
contracts more attractive compared to private deposit contracts. Lack of demand for private deposit contracts translates into no entry by any private bank. Therefore, in this parameter space, LE prevails. It immediately follows that in the absence of a sufficiently high quality of institutions, state banking is the only viable form of savings mobilization.

Notice that due to the symmetry of the model, the private banks that enter in either HE or IE will (a) locate equidistantly from each other, and (b) offer the same deposit rate. The latter is particularly important in IE: irrespective of the equilibrium behavior of opportunistic banks (who breach all of their deposit contracts), the equilibrium deposit rate of any private bank is determined by the profit maximization problem of an honest bank: given the certainty of breach, an opportunistic bank will not want to signal its type by posting a deposit rate different from that of an honest bank (otherwise it will lose all of its potential depositors).

Observe also that in the densely shaded area of Fig. $2 \mathrm{HE}$ and IE co-exist, while in the sparsely shaded area there is no pure strategy equilibrium. The intuition behind the co-existence of HE and IE in the densely shaded area is straightforward. In this parameter space, both $q=1$ and $q=0$ can be optimal (depending on the level of demand). If all players believe that opportunistic banks breach in equilibrium, then depositors' demand for a given private bank and the deposit rate set in accordance with the profit maximization problem of the honest banks (given this demand) is consistent with IE. Thus the belief held by the players that opportunistic banks breach leads to IE being realized. To check that it is unprofitable for a given opportunistic bank to deviate unilaterally from the equilibrium strategy to breach, note that the net benefit from deviating $\left(r-r_{i}\right.$ where $r_{i}$ is set at the level consistent with IE) is smaller than the net benefit from following the equilibrium strategy of breaching $(1+r-\lambda(1+r))$, because $\lambda<1+r_{i}$. Similarly, if the players believe that in equilibrium all opportunistic banks comply with their deposit contracts, then the level of demand for a given private bank deposit contract and the equilibrium deposit rate determined through profit-maximization of an honest bank are going to be consistent with $\mathrm{HE}$, which leads to HE being realized. A unilateral deviation from the equilibrium strategy to comply is suboptimal again: the net benefit of a unilateral breach, $1+r-\lambda(1+r)$, is smaller in this range of $\lambda$-values than the benefit of following the equilibrium strategy of compliance, $r-r_{i}$, where $r_{i}=r-\sqrt{\alpha F}$.

Remark 1 The demand for state deposit contracts is greater when the enforcement probability is 
smaller or the proportion of opportunistic banks is larger.

This result immediately follows from Proposition 1, by noting that in IE $\partial D_{i} / \partial \lambda>0, \partial D_{i} / \partial \gamma<0$, $D_{s}=1-n D_{i}$, and $\left.D_{i}\right|_{L E}<\left.D_{i}\right|_{I E}<\left.D_{i}\right|_{H E}$.

Remark 2 When institutional quality is relatively poor, non-existence of the state bank leads to financial disintermediation.

Non-existence of the state bank in the present setting is qualitatively equivalent to $r_{s}=0$ : in deciding whether to deposit his cash holding in a private bank, the depositor compares the expected gain from private banking with the certain outcome from doing nothing and keeping intact his 1 unit of cash. In the parameter space where IE and LE exist (with $r_{s}=0$ ) in the statement of Proposition 1, non-existence of the state bank implies that the proportion of depositors $D_{s}$ that would have preferred state deposit contracts now prefer to keep their money "under the mattress", in the face of unchecked opportunistic behavior of some private banks.

\subsection{Enforcement externality}

This section considers a modification of the benchmark model. The modification exploits the idea that the resources devoted to enforcement of deposit contracts are fixed and therefore the effectiveness of enforcement (specifically, its likelihood) will decline with the rise of the fraction of breached market contracts. Let $\lambda(q)=\lambda_{0}(1-\delta(1-q))$, where $\lambda_{0}$ is the exogenous level of enforcement available in the economy. Then in HE we have $\lambda_{0}$ while in IE and LE the probability becomes $\lambda_{0}(1-\delta)$. Repeating the analysis of section 2.2 under this modification, the bounds which characterize the equilibria in section 2.2 are re-calculated as follows:

$$
\begin{array}{ll}
\text { if } \lambda_{0} \geq \bar{\lambda} & \text { then } V^{\gamma}(q=1) \geq V^{\gamma}(q=0), \\
\text { if } \lambda_{0}<\tilde{\lambda}_{1} /(1-\delta) \equiv \tilde{\lambda}_{1}^{e} & \text { then } V^{\gamma}(q=1)<V^{\gamma}(q=0), \\
\text { if } \lambda_{0} \leq \tilde{\lambda}_{2} /(1-\delta) \equiv \tilde{\lambda}_{2}^{e} & \text { then } r-r_{i}^{*} \leq 0 \quad \text { where } r_{i}^{*}=\operatorname{argmax}\left\{V^{1-\gamma}\left(r_{i}\right)\right\},
\end{array}
$$

and the analysis leads to a statement similar to that of Proposition 1 except that $\lambda$ must now be substituted with $\lambda_{0}$ in HE or $\lambda_{0}(1-\delta)$ in IE and LE. An important difference in results of the 
enforcement externality case compared to the benchmark case arises from the observation that for $\gamma \in(0,1), \tilde{\lambda}_{1}^{e} \geq 1$ if $\delta \geq \hat{\delta}$ where

$$
\hat{\delta} \equiv \frac{r-r_{s}}{1+r}
$$

with $\hat{\delta} \in(0,1)$ for any $\gamma \in(0,1)$, and in such a case, the "if" part of the statement in (10) is trivially satisfied.

Remark 3 For a sufficiently large enforcement externality, $\delta>\hat{\delta}$, the equilibrium of the game with relatively high institutional quality is no longer unique.

Figure 3: Equilibria of the game with enforcement externality $\delta \geq \hat{\delta}$

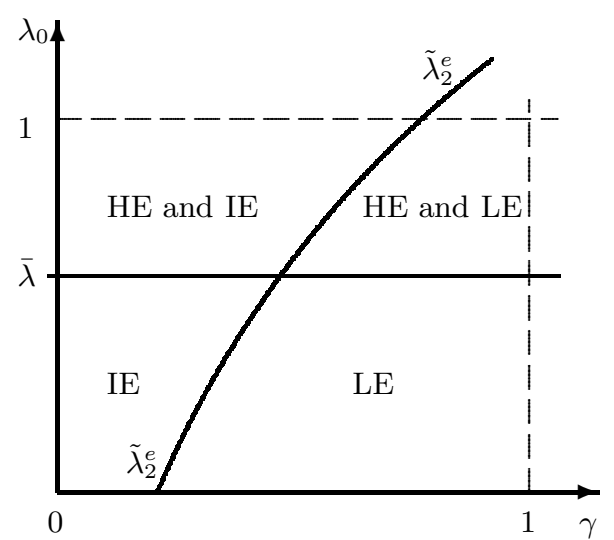

Figure 3 illustrates Remark 3. Intuitively, a relatively high institutional quality is a necessary and sufficient condition of $\mathrm{HE}$ - which is then a unique equilibrium of the game - when the externality is not too large. In such a case, every opportunistic bank prefers to honor its deposit contracts for any positive demand it faces. The bank chooses compliance, rather than breach, because the expected punishment for breach is larger than its benefit due to a high enforcement externality. A not too large enforcement externality means that the behavior of others does not impact on a given breaching bank's chances of being punished. The punishment probability, however, falls as the enforcement externality gets larger. For high enough value of the externality, compliance is no longer an unconditional optimal choice (and therefore relatively high quality of institutions is only a necessary condition for HE). Due to the large externality, compliance is individually optimal if every other opportunistic bank complies because wide-spread compliance guarantees 
that in case of a single breach all of the fixed enforcement resources are devoted to punishing this breach. But if every other opportunistic bank breaches, breach becomes optimal since the fixed enforcement resources are spread too thinly to detect an individual breach with a high probability. The realized equilibrium is, therefore, likely to depend on beliefs regarding institutional quality, which may, in turn, be determined by historical factors, such as whether or not there have been recent episodes of financial instability.

\subsection{The benchmark with government subsidies}

Let the depositor's (net) return from the state deposit contract be

$$
r_{s}^{0}-\alpha /(2 \pi)+s=r_{s}+s,
$$

where $s \in(0,1)$ is the subsidy rate per state deposit contract. The description of feasible equilibria is now given by the following table:

TABLe 2: Description of equilibria in the benchmark with a subsidy.

\begin{tabular}{ccll}
\hline & & & \\
Equilibrium & Breach by opportunists? & Type of banking demanded \\
\hline HES & $q=1$ & state and private & $D_{i}<1 / n$ \\
IES & $q=0$ & state and private & $D_{i}<1 / n$ \\
LES & $q=0$ & state only & $D_{i}=0$ \\
\hline
\end{tabular}

The analysis of section 2.2 is straightforwardly amended to account for (13) and, in the case of high equilibrium with a subsidy (HES) the observation that the marginal depositor located at a distance $\breve{x}_{i}$ between two private banks $i$ and $i+1$ is now indifferent between the nearest private bank, say bank $i$, and the state bank (rather than two private banks, as in HE of the benchmark).

Remark 4 If $s \geq r-r_{s}$ then there is no demand for private deposit contracts.

Clearly, a large subsidy which allows the state bank to offer a net return on its deposit contracts in excess of the exogenously given rate $r$ completely eliminates any competition by private banks. To exclude this uninteresting possibility, it is henceforth assumed that the subsidy is not too large. 
With a positive but not too large subsidy, the threshold values in (7) and (8) now become:

$$
\begin{aligned}
\breve{\lambda} \equiv 1-\frac{r-r_{s}-s}{2(1+r)}, \quad \breve{\lambda}_{1} & \equiv 1-\frac{r-r_{s}-s}{(2-\gamma)(1+r)}, \quad \breve{\lambda}_{2} \equiv 1-\frac{r-r_{s}-s}{\gamma(1+r)}, \\
\breve{n} & \equiv \frac{1}{F}\left(r-\frac{r-r_{s}-s}{2 \alpha}\right) .
\end{aligned}
$$

The conclusions of the analysis with the subsidy are then summarized as follows.

Proposition 2 Assume (A1), (A2), (13) and $s<r-r_{s}$. A unique (pure strategy) equilibrium exists and it is of type:

(i) HES, if $\lambda \geq \breve{\lambda}$. Then $r_{i}=\left(r+r_{s}+s\right) / 2, D_{i}=\left(r-r_{s}-s\right) / \alpha$, and $n<\breve{n}(i=1, \ldots, n)$;

(ii) IES, if $\breve{\lambda}_{2} \leq \lambda<\breve{\lambda}_{1}$. Then $r_{i}=\left[r(1-\gamma)+\gamma(1-\lambda(1+r))+r_{s}+s\right] /[2(1-\gamma)], D_{i}=$ $2 \cdot\left[r(1-\gamma)-r_{s}-s-\gamma(1-\lambda(1+r))\right] / \alpha$ and $n<\breve{n}(i=1, \ldots, n)$;

(iii) LES, if $\lambda<\breve{\lambda}_{2}$. Then $D_{i}=0(i=1, \ldots, n)$, and $n=0$.

The effect of the subsidy is to create a positive demand for state deposit contracts even when all private banks honor their deposit rate promise without fail. The diagram depicting Prop. 2 is drawn below (as before, there is no pure strategy equilibrium in the shaded area). It can also be

Figure 4: Equilibria in the benchmark case with a subsidy $\left(0<s<r-r_{s}\right)$.

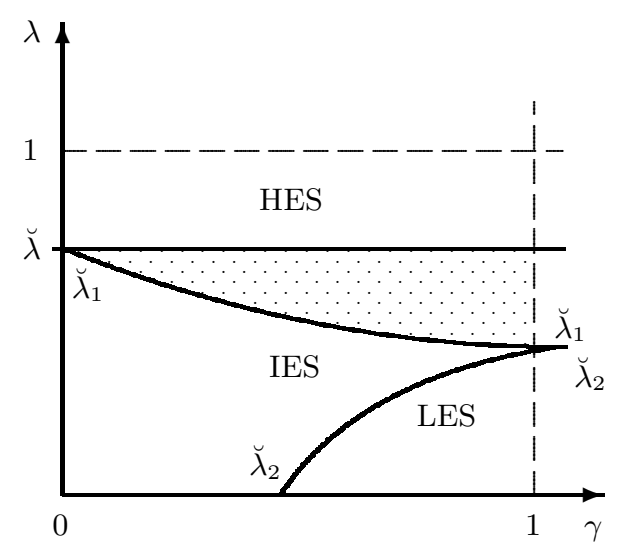

easily checked that the new threshold of the institutional quality for the HES, $\breve{\lambda}$, is higher than 
that for HE, $\bar{\lambda}$ when the subsidy is relatively substantial:

$$
s>r-r_{s}-2 \sqrt{\alpha F} \quad\left(\text { and } s<r-r_{s}\right) .
$$

If it is additionally assumed that $r_{s}=r-3 / 2 \sqrt{\alpha F}$ (ie the largest it could be under the assumption (A2)), then $\breve{\lambda}>\bar{\lambda}$ for any $0<s<r-r_{s}$. Namely, the subsidy makes it harder for private banks to compete with the state bank and hence erodes opportunistic banks' incentive not to cheat their depositors. There is, therefore, a greater need for good institutional quality in order to attain the high equilibrium when the state bank is subsidized. ${ }^{14}$ Reducing or removing government subsidies from state banks will therefore expand the high equilibrium region and release resources that could be used for institution building (e.g., employing enough bank supervisors) thereby providing a double benefit for the economy. Note that once the economy is in the high equilibrium region, the state bank disappears altogether, provided subsidies are withdrawn; there is no need to privatize.

\section{Empirical evidence}

One of the predictions of our model is that where private and government-owned banks co-exist, the former will offer a higher interest rate to depositors, reflecting the higher risk. Available data suggests that this is indeed the case in a range of countries. For example in Russia in 2002 Sberbank - the state owned savings bank - offered interest rates between 8 and $13 \%$ to depositors while the average in the entire banking sector was $16.5 \%{ }^{15}$ In Romania, in March 2005 the state-owned savings bank CEC offered the lowest deposit rate on the market at $8 \%$ for one-year deposits, while its top competitors offered rates above $11 \% .{ }^{16}$ In China today, as in Korea in the 1980s, ${ }^{17}$ a kerb market of non-bank financial institutions co-exists with the state-owned savings banks by offering higher interest rates. Even in developed financial systems, publicly-owned banks are perceived as less risky and are therefore able to raise funds at a lower cost than privatelyowned banks. In Germany, for example, the two most risky of the German public banks have

\footnotetext{
${ }^{14}$ Introducing the subsidy assumption into the analysis of the enforcement externality case of section 2.3 does not yield any further interesting results.

${ }^{15}$ Kandell (2002).

${ }^{16}$ http://www.seeurope.net/en/Story.php?StoryID=54970\&LangID=1

${ }^{17}$ Lee, Lee and Lee (2002, pp. 17-35)
} 
the same long term risk rating as Deutsche Bank (Moody's Aa3 in April 2005, all others score better). ${ }^{18}$ All publicly-owned banks score better than the other top German banks (Dresdner Bank, Commerzbank and Bayerische Hypo- und Vereinsbank).

Another prediction of the model is that the demand for state deposit contracts is inversely related to the probability of deposit contract enforcement and the proportion of opportunistic private banks. While, due to data availability, we are not able to test this prediction directly, we can nevertheless provide empirical evidence on the determinants of the share in state controlled banks in total bank assets for a large number of countries, which can shed additional light on the empirical validity of the model's predictions. The rest of this section, therefore, aims to provide such evidence. The explanatory variables we utilize purport to capture the variables suggested by the theoretical model. The theoretical variables are, of course, not directly observed, so we use the best available proxies for these variables. In addition, in order to check for robustness to more general specifications, we also utilize legal origin variables. These allow us to control for the historical determinants of the share of state banks, which may reflect political factors. This section is structured as follows. Subsection 3.1 explains the measurement of the variables we use in the regressions and their sources. Subsection 3.2 presents the models that are estimated and discusses the estimation method. Subsection 3.3 presents summary statistics of the data, including pairwise correlations between the variables. Subsection 3.4 presents the empirical estimates, while subsection 3.5 contains their interpretation and discussion. Additional robustness checks, which utilize alternative measures of the dependent variable, are reported and discussed in subsection 3.6. Appendix B contains all relevant tables.

\subsection{Measurement and data sources}

\subsubsection{Dependent variable: $g_{i}$}

We utilize the comprehensive dataset of the share of state-owned or state controlled bank assets as a share of total commercial bank assets compiled by Barth et al. (2001) as part of the World Bank survey on bank regulations and supervisory practices (SOB50). ${ }^{19}$ The data describing state

\footnotetext{
${ }^{18}$ www.moodys.com/

${ }^{19}$ The share is denoted here by $g_{i}$ which in terms of our theoretical model is the same as $1-\mu$.
} 
Figure 5: Distribution of SOB50

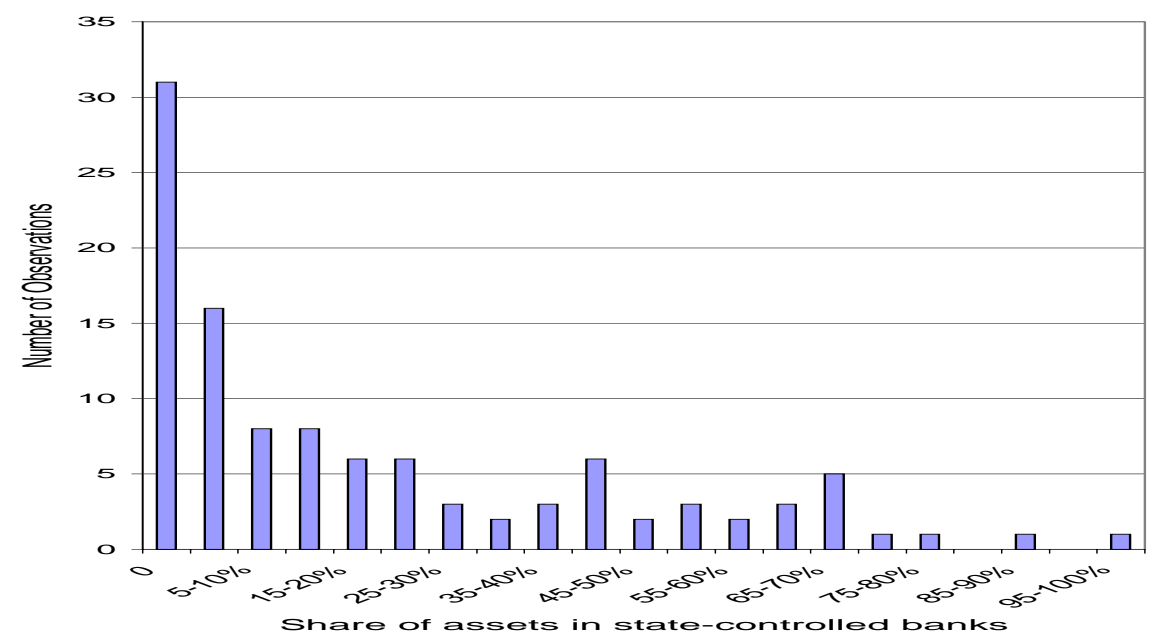

ownership are primarily from 1999, with some responses in late 1998 and early 2000. Data are available for 108 countries. ${ }^{20}$ The SOB50 variable is not evenly distributed, as is shown in Fig. 5. $28 \%$ of the countries in the sample have no state banks. There are no observations of $100 \%$ state ownership, with the highest observed share being $97.1 \% .^{21}$ However, this does not mean that the "low equilibrium" does not exist. The World Bank survey did not receive responses on state-owned banking from countries such as China and Vietnam and did not include countries such as Iran, Libya, Syria and Algeria. All these countries had $99-100 \%$ state ownership in the 1995 dataset of La Porta et al. (2002). Moreover there are no observations for SOB50 from some former Soviet Republics, such as Azerbaijan, Belarus, Tajikistan and Uzbekistan, and African countries, such as Congo, Sierra Leone and Somalia, which are at the bottom of the distribution in terms of regulatory quality and rule of law.

\footnotetext{
${ }^{20}$ Only 83 out of these 108 countries are used in the regressions because of some missing explanatory variables.

${ }^{21}$ This observation is for Turkmenistan and it is the highest in the 108 countries sample. In the sample of 83 countries which we use in our regressions, the highest value of SOB50 is $80 \%$ in India.
} 


\subsubsection{Explanatory variables}

$\lambda$ variable This variable captures the likelihood that cheated depositors will receive compensation. There are problems with measuring this probability directly. A dummy variable showing whether an explicit deposit insurance scheme is in place gives little information on how credible the promise of compensation is in practice. Some countries with explicit deposit insurance schemes have dragged their feet over paying out compensation (e.g. 5 years average waiting time to receive compensation in Kenya), while other countries without explicit guarantees have in fact speedily compensated depositors (e.g. Thailand and Slovenia). ${ }^{22}$ In the model the compensation comes from fines levied against opportunistic banks. Again, there are problems with measuring the probability that legal action is taken against opportunistic banks. Firstly, while some data on the number of bank failures and legal action against bank directors are available in Barth et al. (2001), there is no distinction made between banks that failed because of bad (but not corrupt) lending decisions and those that failed because of managers behaving opportunistically. Secondly, countries that do not report any bank failures could either have no opportunistic banks or tacitly support banks to prevent bank failures.

Therefore our preferred way of creating a proxy for $\lambda$ is to focus on the regulatory environment. One comprehensive database is the Kaufmann, Kraay and Zoido-Lobaton (1999a) database of governance indicators. One of their variables, "regulatory quality", is constructed from a survey of country experts' opinions on the effectiveness of regulation in establishing private markets. ${ }^{23}$ While the regulatory quality index includes measures of "market unfriendly" policies such as price controls and exclusion of foreign competitors from the market, which are not directly indicative of institutional quality, it also includes highly relevant survey results on the adequacy of bank regulation and the effectiveness of financial regulation. Importantly, none of the survey questions on regulatory quality is based on the extent of state-ownership in the economy.

\footnotetext{
${ }^{22}$ There are some data in Barth et al. (2001) on the average time taken to fully compensate depositors the last time a bank failed, but these data are limited, in that they only exist for 37 out of 108 countries in their dataset.

${ }^{23}$ Another potential candidate for a $\lambda$ proxy would be the rule of law indicator in the same database, which contains questions on the enforceability of private contracts and protection of financial wealth from expropriation. However, the indicator also incorporates information on the extent of the black economy, kidnaping of foreigners, tax evasion and personal safety, making this too broad an index for proxying $\lambda$.
} 
A second $\lambda$ proxy utilized in this paper is the "Rule of Law" indicator from the Knack and Keefer IRIS 3 database. International Country Risk Guide (ICRG) compiles this dataset and calls this indicator "Law and Order Tradition". The variable ranges in value from 0 to 6 and "reflects the degree to which the citizens of a country are willing to accept the established institutions to make and implement laws and adjudicate disputes". Higher scores indicate: "sound political institutions, a strong court system, and provisions for an orderly succession of power". Low scores indicate "a tradition of depending on physical force or illegal means to settle claims". We use data which describe rule of law in 1997.

$\gamma$ variable The $\gamma$ proxy is intended to capture the proportion of potentially opportunistic banks in the system. The Barth et al. (2001) database of bank regulations and supervisory practices contains data on specific legal requirements for entry into the banking system, which could, in principle, be used to proxy the probability that opportunistic banks will be granted a bank license. However, the database was constructed in 1999 and by this time most emerging markets had tightened up their prudential requirements in response to a combination of banking crises, technical advice from the international financial institutions and (in Central and Eastern Europe) as part of the EU accession process. There is, therefore, minimal variation in entry requirements across countries. ${ }^{24}$ Also, banking systems that have recently tightened legislation may retain opportunistic banks from previous periods when licensing requirements were more lax. Using the 1999 dataset would not capture this. Finally, the question of whether the law is actually applied or is a mere "paper tiger" would not be addressed.

However, the Barth et al. (2001) database contains specific details of the regulatory environment such as disclosure rules which can provide an alternative way to construct a proxy for $\gamma$. In a regulatory environment that forces banks to disclose information, it is more likely that opportunistic behavior is detected. Stringent disclosure requirements should therefore deter opportunists from applying for a bank license in the first place or would force them to leave the sector once these measures are put in place. ${ }^{25}$ Our $\gamma$ variable is constructed from the following

\footnotetext{
${ }^{24}$ Except for the minimum capital requirement, which, however, is constant throughout the EU and all EU accession candidate countries.

${ }^{25}$ Barth, Caprio and Levine (2002) use a similar index called the "Private Monitoring Index" to measure the extent of private monitoring in the banking system.
} 
three entries in the Barth et al. (2001) database of bank regulations: (i) is accrued but unpaid principal and interest of non-performing loans contained in the income statement ("no" =1, "yes" $=0$, missing entry $=0$ ), (ii) do banks have to publish consolidated balance sheets, (iii) are risk management procedures disclosed. The $\gamma$ proxy is created by adding up the individual dummies, resulting in an index from 0 to $3 .^{26}$ The intuition behind this index is that disclosure requirements regarding non-performing loans and consolidated accounts prevent opportunists from hiding connected lending in their balance sheets or in subsidiary companies. Disclosure of risk management procedures and international ratings indicate a high level of bank monitoring.

A second variable that may capture the proportion of opportunistic banks in the financial system is the share of foreign banks. Foreign banks are only likely to enter a banking system, if they can be reasonably sure that the rule of law applies. A corrupt banking sector would not attract significant foreign entry. ${ }^{27}$ Foreign-owned banks themselves are unlikely to be opportunistic. Subsidiaries of foreign banks would be supervised and managed to the standards of the parent company, as the parent company would be liable for covering losses and needs to protect its brand name and image. A higher share of foreign-owned banks is therefore expected to be associated with a lower proportion of opportunistic banks in the system. Data on the proportion of total assets in banks in which foreign banks hold a share of $50 \%$ or more are available from the Barth et al. (2001) database.

$q$ variable The variable $q$ in the model is the probability that an opportunistic bank will comply with the deposit contract. The results are driven by the perception of depositors regarding the probability of compliance, which determines the demand for private sector savings deposits. Measures of depositors' perceptions of the pervasiveness of opportunistic behavior in the banking sector are not directly available. There are no public surveys about "trust in banks" analogous

\footnotetext{
${ }^{26}$ Our results are robust to alternative definitions of the disclosure index (such as adding the requirement to disclose off-balance sheet items or adding a dummy showing whether the top ten banks are rated by international agencies).

${ }^{27}$ Foreign entry may also be restricted by a government trying to protect an inefficient banking sector from competitors. To that extent the share of foreign banks may also reflect "market unfriendly practices". In that respect the foreign bank share is like the Kaufmann variable, which also contains an aspect of "market unfriendly practices". Including both variables in the regressions may help to disentangle the separate effects of institutional quality and government policy.
} 
to the opinion polls which regularly gauge "trust in politicians". We therefore use a banking crisis dummy as a proxy for investor perceptions about the probability of opportunistic banks cheating. If a country has recently experienced major bank failures depositors are likely to become very cautious about savings in the private sector. The dummy is taken from the comprehensive dataset by Caprio and Klingebiel (2002) on "episodes of systemic and borderline financial crises". Systemic banking crises are defined as episodes during which one of the following is observed: (i) the ratio of non-performing assets to total assets in the banking system exceeds 10\%; (ii) the cost of the rescue operation is at least $2 \%$ of GDP; (iii) banking sector problems result in a large scale nationalization of banks; or (iv) extensive bank runs take place or emergency measures such as deposit freezes, prolonged bank holidays, or generalized deposit guarantees are enacted by the government in response to the crisis.

The banking crisis dummy takes the value 1 if there was a banking crisis (ongoing or starting) between 1990 and 1999. It should be noted that a change in state ownership can occur in two ways after a banking crisis: either savers decide to switch their deposits to state-owned institutions after a collapse of private banks, or the government takes a controlling stake in the failing banks to reassure savers that their deposits will be guaranteed. In the second case, savers who are not happy to retain their deposits in the nationalized bank normally have the option of shifting their deposits into the private sector. ${ }^{28}$

$s$ variable Data on the amount of government subsidies given to state-owned banks are not available. Subsidies could take a variety of different forms such as direct budgetary support, recapitalization, preferential loans from the central bank, buying of non-performing loans by government agencies and guarantees which allow state banks to obtain cheap credit in the international capital markets. We attempt to capture the government's propensity to subsidize with a number of different proxies. ${ }^{29}$ The first proxy is total government consumption as a proportion of GDP, with the intuition that the size of the government sector is an indication of how much

\footnotetext{
${ }^{28}$ If they choose not to do so, this is tantamount to revealing a preference for the state bank.

${ }^{29}$ The closest available proxy for government subsidies to state banks is the "government subsidies to private and public sector enterprises" variable used by Demirgüç-Kunt and Maksimovic (1998). However, the data-set was constructed averaging subsidy levels between 1983-1991, which is well before the time period of our study. Moreover, it is only available for 26 countries. When we include it as an explanatory variable in our regressions it is never significant.
} 
the government intervenes in the economy. The (limited) data-set is taken from the World Development Indicators. The second proxy is taken from Beck, Clark, Groff, Keefer and Walsh (2001) political economy database and concerns the political orientation of the government. A dummy variable is constructed which takes the value 1 for each country that had predominantly left-wing governments in the period from 1995-1997. The intuition here is that left-wing governments have traditionally been more interventionist than center or right-of-center governments. The last of the proxies for propensity to subsidize is based on the IMF MONA database, which records the timing and size of countries' IMF loans. The variable reflects the total amount of loans agreed in the period 1990 to 1998 as a percentage of 1998 GDP. Given the IMF's neo-liberal agenda in the 1990s, one would expect that the more heavily a country relied on IMF funding the more it would have to be seen to subscribe to the "Washington consensus" and therefore would be less able to subsidize state banks.

A summary of all the variables and their sources is shown in Table 3 . Table 4 contains a list of countries used in our regressions, together with their key variables.

\subsubsection{Control variables}

Legal origin variables According to recent research into law and finance, differences in legal traditions may help to explain differences in financial development. ${ }^{30}$ Legal traditions differ in terms of the priority they give to private markets versus state power and in how well private property rights are protected. For the purpose of this analysis legal origin may help to proxy government preferences in maintaining a state-controlled banking system and path dependence in economies which had a large share of state ownership in the past. These factors are independent of the choices depositors make regarding where to place their deposits, which is the main focus of this investigation.

The five legal origin dummies (Anglo-Saxon common law, French civil law, German civil law, Scandinavian civil code and Socialist/Communist law) used are taken from La Porta et al. (1997). We also include additional countries into the socialist origin group, which were excluded from the original sample in La Porta et al. (1997). ${ }^{31}$ For the examination of state ownership of banking,

\footnotetext{
${ }^{30}$ La Porta, Lopez-de-Silanes, Shleifer and Vishny (1997) and Barth et al. (2002).

${ }^{31}$ Albania, Armenia, Estonia, Latvia, Lithuania, Macedonia, Ukraine, and Yugoslavia.
} 
the effect of the socialist legal origin dummy may be expected to be positive, as the socialist countries started the 1990s with close to $100 \%$ state ownership of banking and slowly privatized state-owned banks over the decade while licensing new banks to provide private banking services alongside the declining state sector. Countries with Anglo-Saxon legal origin are more likely to be market-oriented and therefore a lower share of state-ownership in banking is expected. Countries with French, Scandinavian or German legal origins are generally seen as taking a more statecentered approach to banking and hence may be expected to have a higher proportion of state ownership.

\subsection{Methodology}

Firstly, we report raw correlations between each variable and the extent of bank ownership. Secondly, we report maximum likelihood estimation results using the Tobit estimation technique, since our dependent variable, the share of banking system assets held by state-owned or statecontrolled banks, is a limited dependent variable ranging from $0 \%$ to theoretically $100 \%$. In our sample about a quarter of the observations are at the lower limit, i.e. no state banks. There are no observations at the upper limit, with the highest observed share used in the regressions being $80 \%$.

Our theoretical model implies that a single mechanism determines both the outcome when the dependent variable is equal to zero and the magnitude of the dependent variable if it is greater than zero. The Tobit model was developed for exactly this type of problem. ${ }^{32}$ In the Tobit model there is a latent dependent variable $y^{*}=x \beta+u . y^{*}$ is not observed, but a variable $y$ is observed. The observed variable has the following properties:

$$
y=y^{*} \quad \text { if } \quad y^{*}>0 \quad \text { and } \quad y=0 \text { if } y^{*} \leq 0 .
$$

It would be possible to estimate the two outcomes separately. However, as we argue that the same dependent variables explain both outcomes and as the dataset is limited (to at most 83 observations for which all the data are available) it is important that we use the statistically most efficient technique, i.e. the Tobit. ${ }^{33}$ We report the results both excluding and including the legal

\footnotetext{
${ }^{32}$ See, for example, Maddala (1983).

${ }^{33}$ We have also performed the regressions using OLS to compare our results to previous literature in this field, e.g., La Porta et al. (2002). Using OLS does not materially alter our results.
} 
origin variables. ${ }^{34}$ The basic specification is the following:

$$
\begin{aligned}
& g_{i}= \begin{cases}a+b \lambda+c \gamma, & \text { if RHS }>0 \\
0 & \text { otherwise }\end{cases} \\
& g_{i}= \begin{cases}a+b \lambda+c \gamma+e \text { Anglo-Sax }+f \text { Germ }+g \text { Scand }+h \text { Social, if RHS }>0 \\
0 & \text { otherwise }\end{cases}
\end{aligned}
$$

Secondly, we report regression results for simultaneous tests of $\gamma, \lambda$ and $q$ on the state share in the banking system both with and without the legal origin dummies as control variables:

$$
\begin{aligned}
& g_{i}= \begin{cases}a+b \lambda+c \gamma+d q & \text { if RHS }>0 \\
0 & \text { otherwise }\end{cases} \\
& g_{i}= \begin{cases}a+b \lambda+c \gamma+d q+e \text { Anglo-Sax }+f \text { Germ }+g \text { Scand }+h \text { Social, if RHS }>0 \\
0 & \text { otherwise }\end{cases}
\end{aligned}
$$

Finally, we include the different proxies for the subsidies variable in the equations and report regression results for simultaneous tests of $\gamma, \lambda, q$ and $s$ on the state share in the banking system. Again we report results both with and without the legal origin dummies as control variables:

$$
\begin{gathered}
g_{i}= \begin{cases}a+b \lambda+c \gamma+d q+e s, & \text { if RHS }>0 \\
0 & \text { otherwise }\end{cases} \\
g_{i}= \begin{cases}a+b \lambda+c \gamma+d q+e s+f \text { Anglo-Sax }+g \text { Germ }+h \text { Scand }+i \text { Social, if RHS }>0 \\
0 & \text { otherwise }\end{cases}
\end{gathered}
$$

\footnotetext{
${ }^{34}$ We use French legal origin as the baseline group as this is the largest group of countries. However, similar results are obtained when using the Anglo-Saxon legal origin as the base group.
} 


\subsection{Summary statistics}

There was considerable cross-country variation in the share of assets of state-controlled banks in banking systems in 1998 (see Fig. 5). SOB50 ranges from 0\% to 97.1\%. The mean share of banks in which the state had a 50\% share in 1999 was 20.6\%. Predictably, the (formerly) socialist countries had the highest share of government owned banks with a mean of $32.11 \%$. The same countries also had the highest incidence of banking crises and the lowest mean regulatory quality. Scandinavian origin countries showed the highest level of regulatory quality overall. Table 5 contains the summary statistics for our main variables.

The pairwise correlations reported in Table 6 provide a first confirmation of our hypotheses. The percentage of the banking system's assets in state-controlled banks is positively correlated with the incidence of a banking crisis in the 1990s. State control over banking assets is negatively linked with the quality of regulation, rule of law, the extent of disclosure requirements on banks and the share of foreign banks in the financial sector. The three suggested proxies for $s$ are only very weakly correlated with state-ownership of banks, but the signs are as expected with larger governments and left-wing governments being positively and IMF-funded governments being negatively related to state-owned banking.

The proxies for $\gamma, \lambda$ and $q$ are not highly correlated with each other. This is encouraging, because $\gamma$ and $\lambda$ could be strongly linked in principle. The higher the probability of offending banks being caught and punished, the lower is the incentive for opportunists to enter into the banking system. The correlation coefficient between the indicator of regulatory quality and the disclosure requirements on banks is 0.328 , indicating that the two variables capture different aspects of institutional quality. The broader "rule of law" proxy for $\lambda$ is even less strongly linked to the $\gamma$ proxy, with a correlation coefficient of 0.264 . The two proxies for $\lambda$ (regulatory quality and rule of law) are strongly correlated with a correlation coefficient of 0.598. As expected, there is a negative correlation between the $\gamma$ and $\lambda$ proxies and the incidence of banking crises. Government consumption is positively correlated with rule of law and regulatory quality, which could reflect higher tax compliance in countries with more developed enforcement institutions. 


\subsection{Empirical results}

Tables 7, 8 and 9 present the Tobit estimation results for equations (13)-(14), (15)-(16) and (17)(18), respectively. The letters A and C signify the two alternative proxies used for $\lambda$ (regulatory quality and rule of law, respectively). Letter B signifies a further refinement of the regulatory quality variable, which is explained below. Letter $\mathrm{D}$ signifies that the two $\gamma$ proxies are used simultaneously with regulatory quality as the proxy for $\lambda$. In Table 9 , the additional digit accompanying the number of the regression, (17D) or (18D), refers to one of the three different proxies for $s$.

The proxies for $\gamma$ and $\lambda$ are mostly statistically significant at the $1 \%$ or at the $5 \%$ level. The regression coefficients are also relatively robust to different specifications of the equations. The significance level and coefficient for $q$ are especially stable across different specifications of the equation. $^{35}$

Equations (13A) and (14A) use the raw regulatory quality index, which is shown to be highly significant and of the expected sign, with higher regulatory quality decreasing the share of state banks. Similarly, the disclosure index is of the expected sign, with higher disclosure requirements lowering the share of state owned banking. It is significant at $5 \%$ level in both specifications of the regression. None of the legal origin variables is statistically significant.

Equations (13B) and (14B) aim to test whether there is a cut-off point for $\lambda(\bar{\lambda}$ in our theoretical model, see Fig. 2) above which high equilibrium prevails. The regulatory quality variable is, therefore, split into a low regulatory quality spline ( $80 \%$ of the sample) and a high regulatory quality spline (20\% of the sample). While the lower regulatory quality spline remains significant, the high regulatory quality spline loses its statistical significance. This indicates that increases in $\lambda$ cease to have a statistically significant effect on state ownership once a certain threshold of reg-

\footnotetext{
${ }^{35}$ To address the question whether institutional quality is merely a proxy for the level of development, we included GDP per capita in some regressions. Regressions including GDP per capita showed the significance level of the regulatory quality and disclosure indices remaining significant at the $5 \%$ level and the banking crises dummy at the $1 \%$ level. The variables' coefficients were only insignificantly affected. GDP per capita itself is not significant (p-value of 0.646). If GDP per capita is included in the regression instead of the regulatory quality variable, it becomes significant at the 10\% level. GDP per capita may therefore be used as an imperfect proxy for institutional quality, but the level of development does not drive the results.
} 
ulatory quality is reached. ${ }^{36}$ The estimates for the disclosure requirements are almost unchanged and none of the legal origin dummies is statistically significant.

Equations (13C) and (14C) utilize the Knack and Keefer rule of law indicator instead of the Kaufmann regulatory quality variable as the $\lambda$ proxy. These regressions are based on a smaller number of observations than regressions (14A) and (14B). Again, rule of law has effects of the expected sign (higher scores lower the share of state-owned banks) and is statistically significant, at the $10 \%$ level if the legal origins are excluded and at the $1 \%$ level if legal origins are included. For the first time the German dummy and socialist legal origin indicator become statistically significant at the $10 \%$ and $1 \%$ level respectively (equation (14C)). These results suggest that there are some aspects of contract enforcement in the banking systems, which are captured less well by the rule of law indicator than by the regulatory quality index.

The equations (13D) and (14D) include the two $\gamma$ proxies - the disclosure index and the foreign ownership share - simultaneously. Foreign ownership is statistically significant at the $5 \%$ level, while the disclosure index remains significant at the $1 \%$ level. The regulatory quality variable's significance is somewhat reduced in regression $14 \mathrm{D}$ to $5 \%$, which may reflect the overlap between the foreign ownership variable and the "market unfriendly practices" of the Kaufmann variable, or the reduced number of observations for which all data are available. If the former is the case, however, the fact that the regulatory quality variable remains significant confirms that "pure" quality of regulation is an important explanatory factor.

In Table 8 the banking crisis dummy enters, as expected, with a positive coefficient, which is very robust and highly significant mostly at the $1 \%$ level. With one exception, its estimated coefficient is very stable across the different regressions. The qualitative nature of the rest of the results remains unchanged and the regression coefficients of the $\gamma$ proxy remain stable. However, the statistical significance of some variables is somewhat weakened, especially the rule of law variable in regressions $(15 \mathrm{C})$.

Regressions (15A) and (16A) confirm the results of regression (13A) and (14A), with better regulatory quality and higher disclosure requirements reducing the share of state-owned banking.

\footnotetext{
${ }^{36}$ Our results are robust to different splits of the regulatory quality index. The smaller the proportion of the sample in the top group, the greater the significance of the bottom group. The upper part of the regulatory quality spline only becomes significant if it contains more than $20 \%$ of the sample.
} 
Both variables are significant at the $5 \%$ level if the legal origins are excluded and at the $1 \%$ level in the regression with the legal origins. The banking crisis dummy raises state ownership and is significant at the $1 \%$ level.

Regression (16B) re-confirms the existence of a $\lambda$-threshold: among the countries with the highest scores of regulatory quality there is no longer a significant positive effect of further raising regulatory quality. In regression (15B) however, the lower spline is just not statistically significant (11\%). However, a split of $15 \%$ in the top spline and $85 \%$ in the bottom spline restores the significance of the bottom group.

Regression (15C) shows that the rule of law indicator still has the expected effect of lowering state ownership though slightly less statistically significant if the banking crisis dummy is included in the specification. The latter enters the regression positively, as expected, and is significant at the $1 \%$ level. If the legal origin variables are included into the estimation, as is the case in regression (16C), the rule of law indicator improves its statistical significance to the $5 \%$ level. However, this reduces the significance of the banking crisis dummy to the $10 \%$ level. The sensitivity of some of the results in regressions (15C) and (16C) can partly be ascribed to the smaller sample. It may, however, also indicate that the rule of law variable is too broad as a proxy for $\lambda$.

Equations (15D) and (16D) show that the second $\gamma$ proxy of foreign ownership is statistically significant at the $5 \%$ level. It again slightly undermines the significance of the regulatory quality variable to significance at the $5 \%$ level, but the other $\gamma$ proxy and the $q$ proxy retain significance at the $1 \%$ level.

Regressions (17D-1)-(18D-3) in Table 9 examine the effect of the different proxies for $s$ on government ownership of banks. None of the three proxies for government subsidies is statistically significant and only the dummy for left-wing governments is of the expected sign. There is therefore very little direct evidence for subsidies maintaining state ownership of banks. In two of the regressions, however, the Anglo-Saxon legal origin variable is significant at the $10 \%$ level. To the extent that Anglo-Saxon legal origin is indicative of a lesser degree of political interference in the economy and therefore in the banking sector as argued for example in La Porta et al. (1997) this result can be interpreted as providing some, albeit limited, support for the "political view" of government ownership of banks. 


\subsection{Interpretation of empirical results}

The results suggest that after a decade of aggressive privatization, fixed country effects and legal traditions have little influence on the degree of government ownership of banks. Instead, good institutions appear to be the key to fostering a private banking system. High de facto regulatory quality appears to inspire confidence in private sector banking practices and hence reduces the need for state banks as a safe haven for private sector deposits. Similarly, strict disclosure rules, which allow private monitoring of bank behavior, appear to deter opportunists from entering a market. Systemic banking crises seem to alter public perceptions about the risks involved in transacting with private banks. A past banking crisis appears to lower demand for private banking services and encourages depositors to keep their savings in either state banks or banks that have (at least partially) been taken over by the state in the resolution of a banking crisis. Finally, we find only very limited support, if any, for politically motivated subsidies maintaining the state's share in the banking sector. None of the political variables is statistically significant, whereas the institutional variables are consistently significant, have the predicted signs and relatively stable coefficients across different specifications of the regressions.

The economic importance of these results can be examined by calculating various policy effects. In order to illustrate the order of magnitude of these effects we focus on Model 15A, which is our preferred specification. ${ }^{37}$ Increasing regulatory quality by one standard deviation reduces the share of government assets in the banking sector by $8.54 \%$, which is equivalent to just over one third of the standard deviation of the dependent variable. Increasing disclosure by one standard deviation reduces the share of government ownership in banking by $6.51 \%$, which is just over one quarter of its standard deviation. To shed further light on the magnitudes involved, we ran an ancillary regression based on specification 15A, which suggests that improving from the worst quartile of regulatory quality to the best reduces government ownership in banking by $21.4 \%{ }^{38}$ The same regression suggests that improving disclosure from the worst to the best practice can reduce government ownership by an additional $21.0 \%$. These effects are quite large and therefore

\footnotetext{
${ }^{37}$ In the sense that it is the most general specification in which all the explanatory variables suggested by the most general version of the model are included, measured by our preferred proxies and pass the test of statistical significance.

${ }^{38}$ These results are available from the authors upon request.
} 
economically significant. Consequently, it appears that the impact of institutions on government ownership of banks is of first-order importance.

To sum up, the results presented in Section 3.4 are consistent with the predictions of the theoretical model. Specifically, the share of state control over bank assets is inversely related to institutional quality, as measured by the overall quality of regulation or the broader rule of law indicator, and stringent disclosure requirements. Additionally, perceptions of institutional quality, which are likely to be affected by previous banking crises, also seem to be important determinants of the share of state banks. While the theory showed that subsidies might maintain state banks even in the presence of a good regulatory and supervisory environment, our empirical findings suggest that the relative significance of such political interference in the banking sector is at best small, compared to the effects of institutional under-development. Thus, improving the institutions that foster the development of private banks appears to be the key to reducing the role of state banks in the economy.

\subsection{Additional robustness checks}

Additional robustness checks are carried out using alternative measures of the dependent variable. Specifically, we use four of the variables used by La Porta et al. (2002) to measure different aspects of government ownership in banking. ${ }^{39}$ To this end, we re-estimate our preferred specification $15 \mathrm{~A}$, as well as specification 16A (which, in addition to the regulatory, disclosure and banking crisis variables of $15 \mathrm{~A}$, also includes the legal origin dummies). ${ }^{40}$ The La Porta et al. (2002) variables that we utilize are as follows: ${ }^{41}$

(i) GB95: share of the assets of the top ten banks in a given country owned by the government of that country in 1995 .

(ii) GC20: share of the assets of the top ten banks in a given country controlled by the government at the $20 \%$ level in 1995 .

\footnotetext{
${ }^{39}$ We are grateful to an anonymous referee for suggesting this.

${ }^{40}$ In these regressions we use the 1996 values of regulatory quality from Kaufmann et al. (1999a); 1996 is the earliest year for which this variable is available.

${ }^{41}$ All the variables below were multiplied by a factor of 100 to ensure comparability with SOB50.
} 
(iii) GC50: share of the assets of the top ten banks in a given country controlled by the government at the 50\% level in 1995 .

(iv) GC90: share of the assets of the top ten banks in a given country controlled by the government at the $90 \%$ level in $1995 .^{42}$

Among these variables, GC50 is the closest definition to our chosen dependent variable, SOB50 (the share of total banking sector assets of banks in which the government holds a share of at least $50 \%$ ) which closely reflects the considerations of our theoretical model. This is because the public is likely to perceive a bank as state-owned if the government has a $50 \%$ share or higher. However, GC50 is an imperfect proxy for our theoretical variable, with the degree of imperfection increasing in the amount of banking assets held outside the top ten banks. GB95 is highly correlated with GC50 with a correlation coefficient of $97 \%$ and as such it is the second closest variable to our chosen dependent variable. However, it is also focused on the top ten banks instead of the entire banking system. Moreover, it also introduces another source of imperfection because it emphasizes ownership of banking assets instead of ownership of banks. Consider for example the following hypothetical scenario. In country A the government owns $10 \%$ of each of the top ten banks and in country B the government completely owns one bank that its share of assets in the top ten is $10 \%$. In both countries GB95 is 10\%, yet both banks' and depositors' behavior may be rather different. GC90 is conceptually a better proxy for our theoretical variable than GB95, even though 90\% ownership is probably too narrow a definition of government owned banks, since a $50 \%$ share is probably sufficient for a bank to behave as state owned and be perceived as such by depositors. Finally, GC20 is probably the weakest proxy for our theoretical variable, since it provides for too wide a definition of government ownership. Even if the government is the largest shareholder with a $20 \%$ stake in a bank, the bank may not behave as a state bank, especially if the links to the state are indirect, through holding companies. Importantly, governments may be less inclined to allow banks to fail where their share is $50 \%$, compared to cases where it is $20 \%$. Similarly, depositors are much less likely to perceive a bank as government owned at $20 \%$ than at $50 \%$, especially if the links to the government are indirect.

The results of running the Tobit regressions with the La Porta et al. variables are presented in Table 10. The $\lambda$ - and $\gamma$-proxies remain significant at the $5 \%$ level in all the specifications that

\footnotetext{
${ }^{42}$ For further details see Appendix in La Porta et al. (2002).
} 
correspond to Model 15A. Moreover, the coefficients are remarkably similar to those reported in Table 7 . The coefficients for regulatory quality range from -15.02 to -12.39 , compared with -12.64 in Table 7 and are closest for GC50 and GB95, as expected. The coefficients on the disclosure variable range from -13.22 to -10.91 , compared with -10.41 in Table 7 . The banking crisis dummy, which covers the period 1990-95, is however, statistically insignificant in all regressions. Taken together with our earlier results, given that the La Porta variables relate to 1995 while our preferred dependent variable was measured primarily in 1999, these findings suggest that banking crises during 1990-95 led to increased government ownership of banks but only after a considerable lag. This is not surprising given that the usual process of bank restructuring that follows banking crises takes several years to complete.

The specifications that correspond to Model 16A show that among the legal origin dummies, the one that is statistically significant in most regressions is socialist legal origin. Specifically, this dummy is significant at the 10\% level in the GB95 and GC50 regressions and significant at the 1\% level in the GC20 regression. The coefficients corresponding to the socialist origin dummy in these regressions suggest that these economies had around $20 \%$ higher ownership than economies at the same level of institutional development in the case of GB95 and GC50 and 30\% higher ownership in the case of GC20, which being the broadest definition of government ownership counts more banks as state owned. Compared with the results that utilize our preferred dependent variable, these results once again reflect the earlier timing of the La Porta variables, which coincides with the middle phases of the transition process in the formerly socialist economies. Interestingly, in the regression with GC90 variable - which utilizes the narrowest definition of government ownershipthe Anglo-Saxon legal origin dummy is negative and significant at the $10 \%$ level while the socialist dummy is not significant, suggesting that the degree of government ownership in the formerly socialist countries had already declined by 1995. The significance of the legal origin dummies in these four specifications does not take away much from the explanatory power of the regulatory quality variable, which remains significant at conventional levels with very similar coefficients. However, some of the explanatory power of the disclosure variable is lost, as this variable now appears with somewhat smaller coefficients, in the range of -10.39 to -8.16 , even though this variable is still significant at the $10 \%$ level in three of the four regressions. The results are clearly weaker in the case of GC20 but this is the variable which has the weakest association to our theoretical model. 
On balance, therefore, we conclude that these additional robustness checks, if anything, help to bolster the empirical case of our paper. The institutional proxies remain statistically and economically significant, particularly in the case of the dependent variable that classifies banks as state owned when the government has a $50 \%$ share, which is most closely aligned with our theory. The institutional proxies are not as strong in the case of the dependent variable that classifies a bank as state owned when the governments share of ownership is $20 \%$. These findings suggest that $20 \%$ government ownership is not as good a substitute for weak institutions as $50 \%$ government ownership. In other words, depositors are much less likely to be reassured by $20 \%$ government ownership than by $50 \%$ government ownership. The insignificance of the banking crisis dummy in these regressions, together with our earlier results, suggests that banking crises may take a considerable amount of time before they result in a greater share of government ownership in banking.

\section{Concluding comments}

Some aspects of our theoretical model resemble arguments found in the "developmental" view of state banking (Gerschenkron 1962). According to this view, state banks could jump start both financial and economic development when economic institutions are inadequate for private banks to play their developmental role. Our paper certainly formalizes some of these arguments and provides evidence that is consistent with them. However, the paper should not be viewed simply as a modern version of the developmental view of state banking for at least two important reasons. Firstly, in our theoretical model we assume that state banks are inherently less efficient than private banks in terms of their lending and investment decisions, once private banking exceeds a minimal threshold level of development; this is, of course, a key element of the political view of state banking. Secondly, while our findings do imply that at very low levels of institutional quality governments could create state banks to jump start financial and economic development, our main policy implication is that governments should build institutions that foster the development of private banking. Specifically, our empirical results suggest that enhancing market regulation and strengthening disclosure rules are particularly effective means of reducing government ownership 
in banking. ${ }^{43}$ Our theoretical results suggest that these types of institutions are likely to increase depositors' confidence in private banking institutions, by preventing or curbing any opportunistic tendencies that are likely to be present in transitional or less developed banking systems.

Our paper also departs from the political view of state banks in at least two important respects, even though we do assume that private banks are more efficient than state banks. Firstly, it acknowledges the possibility that there are circumstances under which depositors may prefer state banks and in so doing it emphasizes the usefulness of state banks at low levels of institutional development. Secondly, it predicts that privatization of state banks is at best unnecessary and at worst detrimental. According to our model, state banks will die a natural death when they are no longer useful, assuming any subsidies are removed. If they are less efficient than private banks, as suggested by the political view, then, unless they are subsidized, they would be unable to compete with private banks once institutional quality is sufficiently high to prevent opportunistic behavior. At low levels of institutional development, on the other hand, privatization of state banks would be detrimental since no private bank will choose to enter the market due to depositors' mistrust in new private banks. Thus, an important policy implication of our results is that instead of privatizing state banks or, indeed, subsidizing them, governments should build institutions that foster the development of private banks and should remove any subsidies from state banks. Our findings are, therefore, consistent with the literature that emphasizes the first-order importance of institutions for economic growth (Acemoglu, Johnson and Robinson 2001, Kaufmann, Kraay and Zoido-Lobaton 1999b, Berglof and Bolton 2002).

The conclusions of this paper may appear pessimistic. They suggest that there are no easy alternatives to institutions-building if developing countries are to reap the benefits of wellfunctioning financial systems. Institution-building is clearly a process that is frequently long-

\footnotetext{
${ }^{43}$ Good examples of a substantial improvement in regulatory quality (Kaufmann, Kraay and Mastruzzi 2005) accompanied by a reduction in government ownership in banking are Iceland and Lithuania. In both countries banking sector development was greatly enhanced in the process. In Iceland the share of government ownership declined from $71.3 \%$ in 1995 (La Porta et al. 2002) to 0\% by 2001 (Barth, Caprio and Levine 2003). The regulatory quality index increased by 1.29 , which represents an increase of $143 \%$. The ratio of bank deposits to GDP increased by $61 \%$ during 1996-2004 (Beck, Demirgüç-Kunt and Levine 2006). In Lithuania the share of government ownership declined from 44\% in 1998 (Barth et al. 2001) to 12.16\% in 2001 (Barth et al. 2003). The regulatory quality index increased by 0.78 , representing an increase of $105 \%$. Bank deposits to GDP increased by $79.5 \%$ during $1996-2004$ (Beck et al. 2006).
} 
drawn-out, and could well stall due to political economy factors. To end on a more positive note, however, it could be pointed out that the new literature on the political economy of financial development offers a number of fruitful insights that may provide the basis for a better understanding of the mechanisms strengthening the necessary institutions (Rajan and Zingales 2003). Thus, more research into the political economy of institutions for financial development would clearly be highly beneficial.

\section{References}

Acemoglu, D., S. Johnson, and J. Robinson (2001) 'The colonial origins of comparative development.' American Economic Review 91(5), 1369-1401

Akerlof, George A., Paul M. Romer, Robert E. Hall, and N. Gregory Mankiw (1993) 'Looting: The economic underworld of bankruptcy for profit.' Brookings Papers on Economic Activity

Arestis, P., and P. O. Demetriades (1999) 'Financial liberalization: The experience of developing economies.' Eastern Economic Journal 25(4), 441-57

Barth, J., G. Caprio, and R. Levine (2000) 'Banking systems around the globe: Do regulation and ownership affect performance and stability?' World Bank Working Paper \# 2325

(2001) Regulation and Supervision of Banks around the World: A New Database (World Bank)

_ (2002) 'Banking regulation and supervision: What works best?' World Bank Working Paper \# 2725

_ (2003) 'Bank regulation and supervision: World Bank research dataset.' World Bank Working Paper \# 2588

Beck, T., A. Demirgüç-Kunt, and R. Levine (2006) 'A new database on financial development and structure (1960-2004).' World Bank Working Paper \# 2146

Beck, T., G. Clark, A. Groff, P. Keefer, and P. Walsh (2001) 'New tools in comparative political economy: A database on political institutions.' World Bank Economic Review 15(1), 165-76 
Berglof, E., and P. Bolton (2002) 'The great divide and beyond: Financial architecture in transition.' Journal of Economic Perspectives 16(1), 77-100

Caprio, G., and D. Klingebiel (2002) Episodes of Systematic and Borderline Financial Crises. World Bank Database (World Bank)

Demetriades, P., and S. Andrianova (2004) 'Finance and growth: What we know and what we need to know.' In Financial Development and Growth: Explaining the Links, ed. C.A.E. Goodhart (Palgrave Macmillan)

Demirgüç-Kunt, A., and E. Detragiache (1999) 'Financial liberalization and financial fragility.' In Annual World Bank Conference on Development Economics 1998., ed. B. Pleskovic and J. Stiglitz (Washington DC: World Bank: Reuters, Pearson Education) pp. 303-31

Demirgüç-Kunt, A., and V. Maksimovic (1998) 'Law, finance and firm growth.' Journal of Finance $53,2107-37$

Freixas, X., and J.-C. Rochet (1997) Microeconomics of Banking (Cambridge, Mass.: MIT Press)

Gerschenkron, A. (1962) Economic Backwardness in Historical Perspective. A Book of Essays (Cambridge, MA: Harvard University Press)

Kaminsky, G. L., and C. M. Reinhart (1999) 'The twin crises: the causes of banking and balanceof-payments problems.' American Economic Review 89(3), 473-500

Kandell, J. (2002) 'Russian roulette.' Institutional Investor Magazine

Kaufmann, D., A. Kraay, and M. Mastruzzi (2005) 'Governance matters IV: Governance indicators 1996-2004.' World Bank

Kaufmann, D., A. Kraay, and P. Zoido-Lobaton (1999a) 'Aggregating governance indicators.' World Bank Working Paper \# 2195

_ (1999b) 'Governance matters.' World Bank Working Paper \# 2196

La Porta, R., F. Lopez-de-Silanes, A. Shleifer, and R. Vishny (1997) 'Legal determinants of external finance.' Journal of Finance 52, 1131-50 
La Porta, R., F. Lopez-de-Silanes, and A. Shleifer (2002) 'Government ownership of banks.' Journal of Finance 57(1), 265-301

Lee, C., K. Lee, and K. Lee (2002) 'Chaebols, financial liberalisation and economic crisis: Transformation of quasi-internal organization in Korea.' Asian Economic

Maddala, G. S. (1983) Limited-dependent and Qualitative Variables in Econometrics (Cambridge, Mass.: Cambridge University Press)

Perotti, E. (2001) 'Banking regulation in a context of extreme legal underdevelopment: Lessons from the russian meltdown.' In The Wild East: Negotiating the Russian Financial Frontier, ed. P. Westin (Reuters, Pearson Education)

Rajan, R., and L. Zingales (2003) 'The great reversals: The politics of financial development in the 20th century.' Journal of Financial Economics 69(1), 5-50

Rioja, F., and N. Valev (2004) 'Does one size fit all?: A reexamination of the finance and growth relationship.' Journal of Development Economics 74, 429-47

Salop, S. (1979) 'Monopolistic competition with outside goods.' Bell Journal of Economics $10(1), 141-56$

Stiglitz, J. (2002) Globalization and Its Discontents (London: Allen Lane, The Penguin Press)

Tirole, J. (1988) The Theory of Industrial Organization (Cambridge, Massachusetts: MIT Press) 


\section{Appendix A}

\section{Proof of Proposition 1}

For each type of the equilibrium, derive the necessary conditions by specifying the equilibrium behavior of an opportunistic bank, a marginal depositor, and an honest bank.

In HE, for a given level of demand for private banking, an opportunistic bank prefers to comply with its deposit contracts:

$$
r-r_{i} \geq(1+r)(1-\lambda)
$$

the marginal depositor located at $\bar{x}_{i}$ from bank $i$ is indifferent between the two nearest private banks and prefers either of these two banks to the state bank:

$$
\begin{aligned}
& 1+r_{i}-\alpha \cdot \bar{x}_{i}=1+r_{i+1}-\alpha \cdot\left(\frac{1}{n}-\bar{x}_{i}\right), \\
& 1+r_{i}-\alpha \cdot \bar{x}_{i} \geq 1+r_{s}
\end{aligned}
$$

and any private bank sets its deposit rate at a level that maximizes its profits,

$$
\partial V / \partial r_{i}=0 \quad \text { where } V=\left(r-r_{i}\right) D_{i} \quad \text { for any } i=1, \ldots, n \text {. }
$$

From $(22), \bar{x}_{i}=1 /(2 n)+\left(r_{i}-r_{i+1}\right) /(2 \alpha)$, and therefore:

$$
D_{i}=\bar{x}_{i}+\bar{x}_{i-1}=\frac{1}{n}+\frac{2 r_{i}-r_{i+1}-r_{i-1}}{2 \alpha} .
$$

Substituting this into (24) and using symmetry, the profit-maximizing rate of any private bank is equal to:

$$
r_{i}=r-\frac{\alpha}{n} \quad(i=1, \ldots, n) .
$$

Under the free-entry condition, the profits are competed away, and therefore the equilibrium number of banks that enter is found as:

$$
n=\sqrt{\alpha / F}
$$

Substituting (26) and (27) back into (21) and (23), the necessary conditions of HE are formulated as:

$$
\begin{aligned}
\lambda & \geq 1-\frac{\sqrt{\alpha F}}{1+r} \equiv \bar{\lambda} \\
r_{s} & \leq r-\frac{3}{2} \sqrt{\alpha F} .
\end{aligned}
$$


In IE, every opportunistic bank prefers to breach all its deposit contracts:

$$
r-r_{i}<(1+r)(1-\lambda)
$$

Given that all opportunistic banks cheat, the marginal depositor located at $\tilde{x}_{i}$ is indifferent between the nearest private bank $i$ and the state bank:

$$
1+r_{s}=(1-\gamma)\left(1+r_{i}\right)+\gamma \lambda(1+r)-\alpha \tilde{x}_{i}
$$

And an honest bank solves its profit-maximization problem, given that all opportunistic banks breach $(q=0)$. The latter adversely affects the level of demand faced by every private bank:

$$
D_{i}=2 \tilde{x}_{i}=\frac{2}{\alpha} \cdot\left[(1-\gamma) r_{i}-\gamma(1-\lambda(1+r))-r_{s}\right],
$$

which is derived from (31). The profit-maximization problem of an honest bank is solved by setting:

$$
r_{i}=\frac{r(1-\gamma)+r_{s}+\gamma(1-\lambda(1+r))}{2(1-\gamma)}
$$

(Note that an opportunistic bank optimally mimics the honest bank's offer of the deposit rate, since otherwise the depositors could tell the two types of banks apart and would avoid contracting with the opportunists.) Substituting (33) into (30) and re-arranging, we obtain:

$$
\lambda<1-\frac{r-r_{s}}{(2-\gamma)(1+r)} \equiv \tilde{\lambda}_{1}
$$

The ex post profit of an honest bank is positive when the profit-maximizing level of the deposit rate $r_{i}$ in (33) is smaller than $r$ (and therefore $\tilde{x}_{i}>0$ ). This is equivalent to the following additional constraint:

$$
\lambda>1-\frac{r-r_{s}}{\gamma(1+r)} \equiv \tilde{\lambda}_{2}
$$

It is straightforward to check that $\tilde{\lambda}_{1} \in(0,1)$ and $\tilde{\lambda}_{1}>\tilde{\lambda}_{2}$ for any $\gamma \in(0,1), \tilde{\lambda}_{2} \in[0,1)$ if $\gamma \in\left[\left(r-r_{s}\right) /(1+r), 1\right)$, and $\bar{\lambda}>\tilde{\lambda}_{1}$ if $\gamma>\left(2 \sqrt{\alpha F}-\left(r-r_{s}\right)\right) / \sqrt{\alpha F}$. The assumption of free-entry together with the necessary condition of $0<D_{i}<1 / n$ gives an upper bound on the number of private banks that would enter the industry in this equilibrium as follows:

$$
\left(r-r_{i}\right) \cdot 2 \tilde{x}_{i}=F \quad \stackrel{(35)}{\Leftrightarrow} \quad \tilde{x}_{i}=\frac{F}{2\left(r-r_{i}\right)}<\frac{1}{2 n} \quad \Leftrightarrow \quad 0<n<\frac{r-r_{i}}{F} \equiv \tilde{n},
$$

where $r_{i}$ is given by (33). 
Finally, LE is characterized by the same constraints as IE, except that now honest banks find it unprofitable to enter: the level of $r_{i}$ which satisfies FOC of their profit maximization problem results in non-positive ex post profits, i.e., $r-r_{i} \leq 0$ which from the above analysis arises when (35) is invalidated. Non-positive profits imply that honest banks do not enter, and therefore the depositors expect to face a breaching opportunistic private bank with certainty when

$$
\lambda \leq \tilde{\lambda}_{2}
$$

The certainty of breach of a private deposit contract implies that no depositor is willing to bank in the private sector. Hence the equilibrium demand is $D_{i}=0$ for any $n>0$ and $i=1, \ldots, n$ when (36) holds. The equilibrium zero level of demand for private deposit contracts ensures that no private bank enters.

\section{Proof of Remark 3}

To establish the claim, we need to find the range of $\delta$-values for which $\tilde{\lambda}_{1}^{e} \geq 1$, and therefore constraint (10) is validated for any $\gamma \in(0,1)$ :

$$
\tilde{\lambda}_{1}^{e}=\frac{1}{1-\delta} \cdot\left(1-\frac{r-r_{s}}{\gamma(1+r)}\right) \geq 1 \quad \Leftrightarrow \quad \gamma \leq \frac{2 \delta(1+r)-\left(r-r_{s}\right)}{\delta(1+r)} .
$$

The latter is true for any $\gamma \in(0,1)$ if

$$
\frac{2 \delta(1+r)-\left(r-r_{s}\right)}{\delta(1+r)} \geq 1 \quad \Leftrightarrow \quad \delta \geq \frac{r-r_{s}}{1+r} \equiv \hat{\delta} .
$$




\section{Appendix B}

Table 3: Description of Variables and Data Sources

\begin{tabular}{|c|c|c|c|c|}
\hline Variable & Variable name & Definition & Date & Source \\
\hline$g_{i}$ & SOB50 & $\begin{array}{l}\text { Share of total banking sector assets } \\
\text { of banks in which the government } \\
\text { holds a share of at least } 50 \%\end{array}$ & 1999 & Barth et al. (2001) \\
\hline$\lambda_{1}$ & Regulatory quality & $\begin{array}{l}\text { Measure of whether regulation is ef- } \\
\text { fective in promoting private markets }\end{array}$ & $1997 / 1998$ & Kaufmann et al. (1999a) \\
\hline$\lambda_{2}$ & Rule of law & $\begin{array}{l}\text { Reflects the degree to which } \\
\text { the citizens of a country are } \\
\text { willing to accept the established } \\
\text { institutions to adjudicate disputes }\end{array}$ & 1997 & Knack and Keefer, ICRG \\
\hline$\gamma_{1}$ & Disclosure index & $\begin{array}{l}\text { Disclosure rules: consolidated } \\
\text { balance sheets, statement of non- } \\
\text { performing loans, risk management } \\
\text { procedures and top } 5 \text { banks rated } \\
\text { by international agencies (yes }=1, \\
\text { no }=0, \text { missing entry }=0 \text { ). Index } \\
\text { created by adding up dummies }\end{array}$ & 1999 & Barth et al. (2001) \\
\hline$\gamma_{2}$ & Foreign ownership & $\begin{array}{l}\text { Share of total banking sector } \\
\text { assets of banks in which foreign } \\
\text { banks hold a share of at least } 50 \%\end{array}$ & 1999 & Barth et al. (2001) \\
\hline$q$ & Banking crisis dummy & $\begin{array}{l}\text { Perception of the quality of } \\
\text { institutions: Banking crisis } \\
\text { dummy = } 1 \text { if there was a } \\
\text { banking crisis in the } 1990 \text { s }\end{array}$ & $1990 \mathrm{~s}$ & $\begin{array}{l}\text { Caprio and } \\
\text { Klingebiel (2002) }\end{array}$ \\
\hline$S_{1}$ & Govnt consumption & $\begin{array}{l}\text { Government final consumption } \\
\text { expenditure as per cent of GDP }\end{array}$ & 1997 & $\begin{array}{l}\text { World Develop- } \\
\text { ment Indicators }\end{array}$ \\
\hline$S_{2}$ & Left dummy & $\begin{array}{l}\text { Political orientation of government: } \\
\text { left-of-centre }=1 \text {, otherwise } 0\end{array}$ & 1997 & Beck et al. (2001) \\
\hline$S_{3}$ & IMF loans & $\begin{array}{l}\text { Loans agreed with the IMF } \\
\text { over } 1990-1998 \text { period as } \\
\text { a percentage of } 1998 \text { GDP }\end{array}$ & 1997 & $\begin{array}{l}\text { IMF MONA database } \\
\text { (unpublished, avail- } \\
\text { able upon request) }\end{array}$ \\
\hline
\end{tabular}


Table 4: List of Countries and Key Variables

\begin{tabular}{|c|c|c|c|c|c|c|}
\hline Country & SOB50 & $\begin{array}{c}\text { Regulatory } \\
\text { quality }\end{array}$ & Rule of law & $\begin{array}{l}\text { Disclosure } \\
\text { index }\end{array}$ & $\begin{array}{c}\text { Foreign } \\
\text { ownership }\end{array}$ & $\begin{array}{c}\text { Banking } \\
\text { crisis }\end{array}$ \\
\hline Argentina & 30.0 & 0.67 & 5 & 2 & 49.0 & 1 \\
\hline Australia & 0.0 & 0.96 & 6 & 3 & 17.1 & 0 \\
\hline Austria & 4.1 & 0.90 & 6 & 2 & 5.1 & 0 \\
\hline Bahrain & 3.7 & 0.75 & 5 & 3 & 28.0 & 0 \\
\hline Bangladesh & 69.9 & -0.16 & 3 & 1 & 6.4 & 1 \\
\hline Belarus & 67.3 & -1.47 & . & 1 & 2.8 & 1 \\
\hline Bolivia & 0.0 & 0.88 & 3 & 2 & 42.3 & 1 \\
\hline Botswana & 2.4 & 0.57 & 4 & 2 & 97.6 & 0 \\
\hline Brazil & 51.5 & 0.13 & 3 & 2 & 16.7 & 1 \\
\hline Burundi & 63.0 & -0.85 & . & 3 & 0.0 & 1 \\
\hline Cambodia & 16.0 & -0.04 & . & 1 & 71.0 & 0 \\
\hline Canada & 0.0 & 0.87 & 6 & 3 & & 0 \\
\hline Chile & 11.7 & 0.90 & 5 & 2 & 32.0 & 0 \\
\hline Croatia & 37.0 & 0.24 & . & 2 & 6.7 & 1 \\
\hline Cyprus & 3.3 & 0.84 & 5 & 3 & 10.9 & 0 \\
\hline Czech Republic & 19.0 & 0.57 & 6 & 1 & 26.0 & 1 \\
\hline Denmark & 0.0 & 1.05 & 6 & 2 & . & 0 \\
\hline Egypt & 66.6 & 0.12 & 4 & 2 & 4.2 & 1 \\
\hline Estonia & 0.0 & 0.74 & . & 2 & 85.0 & 1 \\
\hline Finland & 21.9 & 1.14 & 6 & 3 & 7.8 & 1 \\
\hline France & 0.0 & 0.71 & 5 & 1 & . & 1 \\
\hline Gambia & 0.0 & -0.25 & 5 & 2 & 76.4 & 0 \\
\hline Germany & 42.0 & 0.89 & 6 & 1 & 4.2 & 0 \\
\hline Ghana & 37.9 & 0.28 & 3 & 1 & 54.3 & 0 \\
\hline Greece & 13.0 & 0.61 & 5.3 & 1 & 5.0 & 0 \\
\hline Guatemala & 7.6 & 0.44 & 3 & 1 & 4.9 & 0 \\
\hline Guyana & 19.0 & 0.23 & 4 & 2 & 16.0 & 0 \\
\hline Honduras & 1.1 & 0.08 & 3 & 1 & 1.6 & 0 \\
\hline Hungary & 3.0 & 0.85 & 6 & 2 & 62.0 & 1 \\
\hline Iceland & 64.0 & 0.61 & 6 & 2 & 0.0 & 0 \\
\hline India & 80.0 & -0.04 & 4 & 1 & 0.0 & 1 \\
\hline Indonesia & 44.0 & 0.12 & 4 & 2 & 7.0 & 1 \\
\hline Italy & 17.0 & 0.59 & 6 & 2 & 5.0 & 0 \\
\hline Jamaica & 56.0 & 0.76 & 3 & 2 & 44.0 & 1 \\
\hline Japan & 1.2 & 0.39 & 6 & 2 & 5.9 & 1 \\
\hline Jordan & 0.0 & 0.42 & 4 & 2 & 68.0 & 0 \\
\hline Korea & 29.7 & 0.22 & 4 & 3 & 0.0 & 1 \\
\hline Kuwait & 0.0 & -0.09 & 6 & 3 & 0.0 & 0 \\
\hline Lebanon & 0.0 & 0.10 & 4 & 3 & 27.2 & 0 \\
\hline Lesotho & 51.0 & -0.06 & . & 2 & 49.0 & 0 \\
\hline
\end{tabular}




\begin{tabular}{|c|c|c|c|c|c|c|}
\hline Country & SOB50 & $\begin{array}{c}\text { Regulatory } \\
\text { quality }\end{array}$ & Rule of law & $\begin{array}{l}\text { Disclosure } \\
\text { index }\end{array}$ & $\begin{array}{c}\text { Foreign } \\
\text { ownership }\end{array}$ & $\begin{array}{c}\text { Banking } \\
\text { crisis }\end{array}$ \\
\hline Lithuania & 44.0 & 0.09 & . & 2 & 48.0 & 1 \\
\hline Luxembourg & 5.0 & 0.95 & 6 & 2 & 95.0 & 0 \\
\hline Macedonia & 0.5 & -0.31 & . & 2 & 92.7 & 1 \\
\hline Malawi & 48.9 & 0.08 & 4 & 2 & 8.3 & 0 \\
\hline Malaysia & 0.0 & 0.48 & 5 & 2 & 18.0 & 1 \\
\hline Malta & 0.0 & 0.39 & 6 & 3 & 48.8 & 0 \\
\hline Mauritius & 0.0 & 0.22 & . & 2 & 25.8 & 0 \\
\hline Mexico & 25.0 & 0.61 & 3 & 2 & 19.9 & 1 \\
\hline Moldova & 7.1 & -0.28 & . & 2 & 33.4 & 0 \\
\hline Morocco & 23.9 & 0.22 & 6 & 2 & 18.8 & 0 \\
\hline Nepal & 20.0 & -0.36 &. & 1 & 35.0 & 0 \\
\hline Netherlands & 5.9 & 1.14 & 6 & 3 & . & 0 \\
\hline New Zealand & 0.0 & 1.21 & 6 & 3 & 99.0 & 0 \\
\hline Nigeria & 13.0 & -0.35 & 3 & 2 & 0.0 & 1 \\
\hline Oman & 0.0 & 0.31 & 5 & 2 & 11.1 & 0 \\
\hline Panama & 11.6 & 1.00 & 3 & 2 & 38.3 & 0 \\
\hline Peru & 2.5 & 0.67 & 3 & 2 & 40.4 & 0 \\
\hline Philippines & 12.1 & 0.57 & 4 & 3 & 12.8 & 1 \\
\hline Poland & 43.7 & 0.57 & 5 & 2 & 26.4 & 1 \\
\hline Portugal & 20.8 & 0.89 & 5.3 & 2 & 11.7 & 0 \\
\hline Puerto Rico & 0.0 & 0.85 & . & 2 & 30.8 & 0 \\
\hline Qatar & 43.4 & 0.33 & 6 & 2 & 14.9 & 0 \\
\hline Romania & 70.0 & 0.20 & 5 & 1 & 8.0 & 1 \\
\hline Russia & 68.0 & -0.30 & 4 & 2 & 9.0 & 1 \\
\hline Rwanda & 50.0 & -1.17 & . & 1 & 50.0 & 1 \\
\hline Salvador, El & 7.0 & 1.23 & . & 2 & 12.5 & 1 \\
\hline Saudi Arabia & 0.0 & -0.15 & 5 & 3 & 0.0 & 0 \\
\hline Singapore & 0.0 & 1.25 & 6 & 3 & 50.0 & 0 \\
\hline Slovenia & 39.6 & 0.53 & . & 2 & 4.6 & 1 \\
\hline South Africa & 0.0 & 0.24 & 3.7 & 3 & 5.2 & 0 \\
\hline Spain & 0.0 & 0.86 & 5.9 & 2 & 11.0 & 0 \\
\hline Sri Lanka & 55.0 & 0.62 & 4 & 3 & . & 1 \\
\hline Sweden & 0.0 & 0.85 & 6 & 1 & 1.8 & 1 \\
\hline Switzerland & 15.0 & 0.88 & 6 & 3 & 8.5 & 0 \\
\hline Taiwan & 43.0 & 0.83 & 4 & 2 & . & 0 \\
\hline Tajikistan & 7.4 & -1.52 & . & 2 & 6.2 & 0 \\
\hline Thailand & 30.7 & 0.19 & 5 & 1 & 7.2 & 1 \\
\hline Trinidad \& Tobago & 15.0 & 0.72 & 4 & 2 & 7.9 & 0 \\
\hline Turkey & 35.0 & 0.60 & 4 & 1 & 66.3 & 0 \\
\hline United Kingdom & 0.0 & 1.21 & 6 & 3 & . & 0 \\
\hline United States & 0.0 & 1.14 & 6 & 2 & 4.7 & 0 \\
\hline Venezuela & 4.9 & 0.09 & 4 & 2 & 33.7 & 1 \\
\hline Zambia & 23.0 & 0.25 & 4 & 2 & 64.0 & 1 \\
\hline
\end{tabular}


TABle 5: Summary Statistics

\begin{tabular}{lcccccc}
\hline Variable name & Variable & Observations & Mean & Std. deviation & Minimum & Maximum \\
\hline Government ownership & $g_{i}$ & 108 & 20.60 & 24.87 & 0.0 & 97.10 \\
Regulatory quality & $\lambda_{1}$ & 93 & 0.28 & 0.68 & -1.93 & 1.25 \\
Rule of law & $\lambda_{2}$ & 71 & 4.73 & 1.12 & 2.70 & 6.0 \\
Disclosure index & $\gamma_{1}$ & 98 & 2.00 & 0.63 & 1.0 & 3.0 \\
Foreign ownership & $\gamma_{2}$ & 91 & 33.13 & 32.60 & 0.0 & 100.0 \\
Banking crisis dummy & $q$ & 106 & 0.40 & 0.49 & 0.0 & 1.0 \\
\hline
\end{tabular}

TABLE 6: Correlations

\begin{tabular}{cccccccccc}
\hline & SOB50 & $\begin{array}{c}\text { Banking } \\
\text { Crisis Dummy }\end{array}$ & $\begin{array}{c}\text { Regulatory } \\
\text { Quality }\end{array}$ & $\begin{array}{c}\text { Rule } \\
\text { of Law }\end{array}$ & $\begin{array}{c}\text { Disclosure } \\
\text { Index }\end{array}$ & $\begin{array}{c}\text { Foreign } \\
\text { Ownership }\end{array}$ & $\begin{array}{c}\text { Government } \\
\text { Consumption }\end{array}$ & $\begin{array}{c}\text { Left } \\
\text { Dummy }\end{array}$ & $\begin{array}{c}\text { IMF } \\
\text { Loans }\end{array}$ \\
\hline & 1 & 2 & 3 & 4 & 5 & 6 & 7 & 8 & 9 \\
\hline 1 & 1.0000 & & & & & & & & \\
2 & 0.3767 & 1.0000 & & & & & & \\
3 & -0.4217 & -0.2370 & 1.0000 & & & & & \\
4 & -0.3152 & -0.2427 & 0.5984 & 1.0000 & & & & \\
5 & -0.3478 & -0.2327 & 0.3284 & 0.2639 & 1.0000 & & & \\
6 & -0.2811 & -0.1562 & 0.1849 & -0.0585 & -0.0383 & 1.0000 & & \\
7 & 0.0113 & 0.0627 & 0.3979 & 0.5042 & -0.0787 & 0.0155 & 1.0000 & & \\
8 & 0.1152 & -0.0137 & 0.0181 & 0.1170 & 0.0600 & -0.1335 & 0.1225 & 1.0000 & \\
9 & -0.0306 & 0.2603 & -0.2030 & -0.3013 & -0.0238 & 0.2802 & -0.2182 & 0.0027 & 1.0000 \\
\hline
\end{tabular}


TABLE 7: Government Ownership of Banks and Institutions

Dependent variable: SOB50

\begin{tabular}{|c|c|c|c|c|c|c|c|c|}
\hline $\begin{array}{l}\text { Regression } \\
\text { Variables }\end{array}$ & $13 \mathrm{~A}$ & $14 \mathrm{~A}$ & 13B & $14 \mathrm{~B}$ & $13 \mathrm{C}$ & $14 \mathrm{C}$ & 13D & $14 \mathrm{D}$ \\
\hline \multicolumn{9}{|l|}{$\lambda$} \\
\hline Regul. quality & $\begin{array}{c}-16.16^{* * *} \\
(5.52)\end{array}$ & $\begin{array}{c}-16.45^{* * *} \\
(5.87)\end{array}$ & & & & & $\begin{array}{c}-13.33^{* * *} \\
(5.27)\end{array}$ & $\begin{array}{c}-12.40^{* *} \\
(5.64)\end{array}$ \\
\hline Low reg.qual. spline & & & $\begin{array}{c}-12.53^{* *} \\
(6.36)\end{array}$ & $\begin{array}{c}-13.03^{* *} \\
(6.60)\end{array}$ & & & & \\
\hline High reg.qual. spline & & & $\begin{array}{r}-52.77 \\
(33.65)\end{array}$ & $\begin{array}{c}-53.43 \\
(34.72)\end{array}$ & & & & \\
\hline Rule of law & & & & & $\begin{array}{c}-7.02^{*} \\
(3.18)\end{array}$ & $\begin{array}{c}-10.60^{* * *} \\
(3.33)\end{array}$ & & \\
\hline \multicolumn{9}{|l|}{$\gamma$} \\
\hline Disclosure index & $\begin{array}{c}-11.87^{* *} \\
(4.84)\end{array}$ & $\begin{array}{c}-11.43^{* *} \\
(4.88)\end{array}$ & $\begin{array}{c}-10.78^{* *} \\
(4.90)\end{array}$ & $\begin{array}{c}-10.41^{* *} \\
(4.92)\end{array}$ & $\begin{array}{c}-14.47^{* * *} \\
(5.35)\end{array}$ & $\begin{array}{c}-11.02^{* *} \\
\text { (5.22) }\end{array}$ & $\begin{array}{c}-15.00^{* * *} \\
(4.75)\end{array}$ & $\begin{array}{c}-14.27^{* * *} \\
(4.74)\end{array}$ \\
\hline Foreign ownership & & & & & & & $\begin{array}{c}-0.27^{* *} \\
(0.11)\end{array}$ & $\begin{array}{c}-0.30^{* *} \\
(0.12)\end{array}$ \\
\hline \multicolumn{9}{|l|}{ Legal origin } \\
\hline Anglo-Saxon & & $\begin{array}{c}2.98 \\
(8.60)\end{array}$ & & $\begin{array}{l}-1.83 \\
(8.65)\end{array}$ & & $\begin{array}{l}-0.56 \\
(8.57)\end{array}$ & & $\begin{array}{r}-11.68 \\
(9.00)\end{array}$ \\
\hline German & & $\begin{array}{c}15.30 \\
(13.18)\end{array}$ & & $\begin{array}{c}14.56 \\
(11.45)\end{array}$ & & $\begin{array}{c}21.2^{*} \\
(11.56)\end{array}$ & & $\begin{array}{c}1.56 \\
(12.00)\end{array}$ \\
\hline Scandinavian & & $\begin{array}{c}8.52 \\
(14.75)\end{array}$ & & $\begin{array}{c}11.64 \\
(14.90)\end{array}$ & & $\begin{array}{c}18.36 \\
(14.93)\end{array}$ & & $\begin{array}{c}7.8 \\
(15.33)\end{array}$ \\
\hline Socialist & & $\begin{array}{c}6.93 \\
(8.64)\end{array}$ & & $\begin{array}{c}7.19 \\
(8.58)\end{array}$ & & $\begin{array}{c}31.87^{* * *} \\
(12.57)\end{array}$ & & $\begin{array}{c}6.74 \\
(7.97)\end{array}$ \\
\hline Constant & $\begin{array}{c}46.19^{* * *} \\
(9.72)\end{array}$ & $\begin{array}{c}43.21^{* * *} \\
(10.05)\end{array}$ & $\begin{array}{c}44.47^{* * *} \\
(9.79)\end{array}$ & $\begin{array}{c}41.42^{* * *} \\
(10.11)\end{array}$ & $\begin{array}{l}77.11^{* *} \\
(16.77)\end{array}$ & $\begin{array}{c}81.61^{* * *} \\
(16.33)\end{array}$ & $\begin{array}{c}58.61^{* * *} \\
(9.99)\end{array}$ & $\begin{array}{c}57.78^{* * *} \\
(10.49)\end{array}$ \\
\hline $\mathbf{N}$ of observations & 83 & 83 & 83 & 83 & 67 & 67 & 76 & 76 \\
\hline Log Likelihood & -300.00 & -298.53 & -299.37 & -297.94 & -236.55 & -232.02 & -277.62 & -275.83 \\
\hline
\end{tabular}

$* * *, * *$ and $*$ indicate significance at the $1 \%, 5 \%$ and $10 \%$ level, respectively.

Standard errors in parentheses. 
TABle 8: Government Ownership of Banks, Institutions and Banking Crises

Dependent variable: SOB50

\begin{tabular}{|c|c|c|c|c|c|c|c|c|}
\hline $\begin{array}{l}\text { Regression } \\
\text { Variables }\end{array}$ & $15 \mathrm{~A}$ & $16 \mathrm{~A}$ & 15B & 16B & $15 \mathrm{C}$ & $16 \mathrm{C}$ & 15D & $16 \mathrm{D}$ \\
\hline \multicolumn{9}{|l|}{$\lambda$} \\
\hline Regulatory quality & $\begin{array}{c}-12.64^{* *} \\
(5.20)\end{array}$ & $\begin{array}{c}-14.23^{* * *} \\
(5.49)\end{array}$ & & & & & $\begin{array}{c}-10.55^{* *} \\
\text { (4.92) }\end{array}$ & $\begin{array}{c}-10.86^{* *} \\
(5.26)\end{array}$ \\
\hline Low reg.qual. spline & & & $\begin{array}{l}-9.57 \\
(5.94)\end{array}$ & $\begin{array}{c}-11.91^{*} \\
(6.14)\end{array}$ & & & & \\
\hline High reg.qual. spline & & & $\begin{array}{l}-44.99 \\
(31.70)\end{array}$ & $\begin{array}{l}-44.25 \\
(33.13)\end{array}$ & & & & \\
\hline Rule of law & & & & & $\begin{array}{l}-5.02^{*} \\
(3.04)\end{array}$ & $\begin{array}{c}-8.15^{* *} \\
(3.46)\end{array}$ & & \\
\hline \multicolumn{9}{|l|}{$\gamma$} \\
\hline Disclosure index & $\begin{array}{c}-10.41^{* * *} \\
(4.51)\end{array}$ & $\begin{array}{c}-10.15^{* *} \\
(4.55)\end{array}$ & $\begin{array}{c}-9.47^{* *} \\
(4.57)\end{array}$ & $\begin{array}{c}-9.36^{* *} \\
(4.60)\end{array}$ & $\begin{array}{c}-12.55^{* *} \\
(5.05)\end{array}$ & $\begin{array}{c}-10.66^{* *} \\
(5.08)\end{array}$ & $\begin{array}{c}-13.71^{* * *} \\
(4.42)\end{array}$ & $\begin{array}{c}-13.42^{* * *} \\
(4.43)\end{array}$ \\
\hline Foreign Ownership & & & & & & & $\begin{array}{c}-0.24^{* *} \\
(0.10)\end{array}$ & $\begin{array}{c}-0.27^{* *} \\
(0.11)\end{array}$ \\
\hline \multicolumn{9}{|l|}{$q$} \\
\hline Banking crisis dummy & $\begin{array}{c}19.84^{* * *} \\
(5.76) \\
\end{array}$ & $\begin{array}{c}20.84^{* * * *} \\
(6.10)\end{array}$ & $\begin{array}{c}19.62^{* * *} \\
(5.74)\end{array}$ & $\begin{array}{c}20.47^{* * * *} \\
(6.09)\end{array}$ & $\begin{array}{c}18.97^{* * * *} \\
(6.79)\end{array}$ & $\begin{array}{l}14.06^{*} \\
(7.44) \\
\end{array}$ & $\begin{array}{c}18.77^{* * *} \\
(5.82)\end{array}$ & $\begin{array}{c}19.51^{* * *} \\
(5.82)\end{array}$ \\
\hline \multicolumn{9}{|l|}{ Legal origin } \\
\hline Anglo-Saxon & & $\begin{array}{l}-5.88 \\
(8.17)\end{array}$ & & $\begin{array}{l}-5.1 \\
(8.23)\end{array}$ & & $\begin{array}{l}-3.16 \\
(8.52)\end{array}$ & & $\begin{array}{r}-14.00 \\
(8.55)\end{array}$ \\
\hline German & & $\begin{array}{c}13.88 \\
(10.68)\end{array}$ & & $\begin{array}{c}13.34 \\
(10.63)\end{array}$ & & $\begin{array}{c}18.52 \\
(11.29)\end{array}$ & & $\begin{array}{l}-0.21 \\
(11.1)\end{array}$ \\
\hline Scandinavian & & $\begin{array}{c}3.7 \\
(13.75)\end{array}$ & & $\begin{array}{c}6.27 \\
(13.99)\end{array}$ & & $\begin{array}{l}11.78 \\
(14.93)\end{array}$ & & $\begin{array}{c}1.42 \\
(14.25)\end{array}$ \\
\hline Socialist & & $\begin{array}{l}-2.92 \\
(8.48)\end{array}$ & & $\begin{array}{l}-2.59 \\
(8.45)\end{array}$ & & $\begin{array}{c}20.28 \\
(13.58)\end{array}$ & & $\begin{array}{l}-2.81 \\
(7.87)\end{array}$ \\
\hline Constant & $\begin{array}{c}33.55^{* * *} \\
(9.67)\end{array}$ & $\begin{array}{c}33.39 * * * \\
(9.74)\end{array}$ & $\begin{array}{c}32.2^{* * *} \\
(9.72)\end{array}$ & $\begin{array}{c}32.16^{* * *} \\
(9.78)\end{array}$ & $\begin{array}{c}56.36^{* * *} \\
(17.20)\end{array}$ & $\begin{array}{c}65.85^{* * *} \\
(17.78)\end{array}$ & $\begin{array}{c}46.12^{* * *} \\
(9.84)\end{array}$ & $\begin{array}{c}48.72^{* * *} \\
(10.10)\end{array}$ \\
\hline $\mathbf{N}$ of observations & 83 & 83 & 83 & 83 & 67 & 67 & 76 & 76 \\
\hline Log Likelihood & -294.39 & -292.98 & -293.84 & -292.55 & -232.83 & -230.27 & -272.05 & -270.60 \\
\hline
\end{tabular}

$* * *, * *$ and $*$ indicate significance at the $1 \%, 5 \%$ and $10 \%$ level, respectively.

Standard errors in parentheses. 
TABle 9: Government Ownership of Banks and Government Propensity to Subsidies Dependent variable: SOB50

\begin{tabular}{|c|c|c|c|c|c|c|}
\hline Regression & 17D-1 & 18D-1 & 17D-2 & 18D-2 & 17D-3 & 18D-3 \\
\hline \multicolumn{7}{|l|}{ Variables } \\
\hline \multicolumn{7}{|l|}{$\lambda$} \\
\hline \multirow[t]{2}{*}{ Regulatory quality } & $-9.16^{*}$ & $-9.87^{*}$ & $-10.52^{* *}$ & $-10.84^{* *}$ & $-9.71^{*}$ & $-10.51^{*}$ \\
\hline & (5.22) & (5.62) & $(4.93)$ & $(5.26)$ & $(5.05)$ & $(5.36)$ \\
\hline \multicolumn{7}{|l|}{$\gamma$} \\
\hline \multirow[t]{2}{*}{ Disclosure index } & $-14.72^{* * *}$ & $-14.07 * * *$ & $-13.67^{* * *}$ & $-13.39 * * *$ & $-13.73^{* * *}$ & $-13.39 * * *$ \\
\hline & $(4.87)$ & $(4.96)$ & $(4.42)$ & $(4.44)$ & $(4.42)$ & $(4.42)$ \\
\hline \multirow[t]{2}{*}{ Foreign Ownership } & $-0.18^{*}$ & $-0.23^{*}$ & $-0.28^{* *}$ & $-0.28^{* *}$ & $-0.25^{* *}$ & $-0.28^{* *}$ \\
\hline & $(0.11)$ & $(0.13)$ & $(0.10)$ & $(0.12)$ & $(0.10)$ & $(0.11)$ \\
\hline \multicolumn{7}{|l|}{$q$} \\
\hline \multirow[t]{2}{*}{ Banking crisis dummy } & $17.92^{* * *}$ & $19.97^{* * *}$ & $18.73^{* * *}$ & $19.58^{* * *}$ & $19.30^{* * *}$ & $20.43^{* * *}$ \\
\hline & $(3.86)$ & (6.65) & $(5.46)$ & (5.84) & $(5.48)$ & $(5.90)$ \\
\hline \multicolumn{7}{|l|}{$S$} \\
\hline \multirow[t]{2}{*}{ Government consumption } & -0.11 & -0.13 & & & & \\
\hline & $(0.54)$ & $(0.61)$ & & & & \\
\hline \multirow[t]{2}{*}{ Left dummy } & & & 1.00 & 0.97 & & \\
\hline & & & $(5.77)$ & (5.92) & & \\
\hline \multirow[t]{2}{*}{ IMF loans } & & & & & 0.30 & 0.21 \\
\hline & & & & & $(0.39)$ & $(0.35)$ \\
\hline \multicolumn{7}{|l|}{ Legal origin } \\
\hline \multirow[t]{2}{*}{ Anglo-Saxon } & & $-15.79^{*}$ & & $-14.26^{*}$ & & -13.95 \\
\hline & & (5.62) & & $(8.70)$ & & $(8.65)$ \\
\hline \multirow[t]{2}{*}{ German } & & -1.02 & & -0.23 & & -0.21 \\
\hline & & (12.53) & & (11.1) & & (11.08) \\
\hline \multirow[t]{2}{*}{ Scandinavian } & & 2.5 & & 0.94 & & 1.43 \\
\hline & & $(15.61)$ & & $(14.56)$ & & (14.23) \\
\hline \multirow[t]{2}{*}{ Socialist } & & -6.03 & & -3.06 & & -3.71 \\
\hline & & $(9.41)$ & & (8.02) & & $(7.96)$ \\
\hline \multirow[t]{2}{*}{ Constant } & $47.73^{* * *}$ & $50.67 * * *$ & $45.76^{* * *}$ & $48.46^{* * *}$ & $44.88^{* * *}$ & $47.79 * * *$ \\
\hline & $(11.97)$ & (12.29) & $(10.05)$ & $(10.23)$ & (9.84) & $(10.13)$ \\
\hline $\mathbf{N}$ of observations & 64 & 64 & 76 & 76 & 75 & 75 \\
\hline Log Likelihood & -224.91 & -223.17 & -272.04 & -270.51 & -267.07 & -265.56 \\
\hline
\end{tabular}

$* * *, * *$ and $*$ indicate significance at the $1 \%, 5 \%$ and $10 \%$ level, respectively.

Standard errors in parentheses. 
TABle 10: Additional Robustness Checks

Dependent variable is taken from La Porta et al. (2002)

\begin{tabular}{|c|c|c|c|c|c|c|c|c|}
\hline \multirow[t]{3}{*}{ Dependent variable } & \multirow{2}{*}{\multicolumn{2}{|c|}{$\begin{array}{c}\text { GB95 } \\
\text { Model }\end{array}$}} & \multirow{2}{*}{\multicolumn{2}{|c|}{$\begin{array}{c}\text { GC50 } \\
\text { Model }\end{array}$}} & \multirow{2}{*}{\multicolumn{2}{|c|}{$\begin{array}{c}\text { GC90 } \\
\text { Model }\end{array}$}} & \multirow{2}{*}{\multicolumn{2}{|c|}{$\begin{array}{c}\text { GC20 } \\
\text { Model }\end{array}$}} \\
\hline & & & & & & & & \\
\hline & $15 A$ & $16 A$ & $15 A$ & $16 \mathrm{~A}$ & $15 A$ & $16 \mathrm{~A}$ & $15 A$ & $16 A$ \\
\hline \multicolumn{9}{|l|}{ Explanatory variable } \\
\hline \multirow[t]{2}{*}{ Regulatory quality } & $-12.64^{* *}$ & $-11.80^{* *}$ & $-12.39 * *$ & $-12.68^{*}$ & $-15.02 * * *$ & $-17.59^{* * *}$ & $-14.78^{* *}$ & $-12.17^{*}$ \\
\hline & $(5.15)$ & $(5.55)$ & $(6.05)$ & $(6.49)$ & $(5.45)$ & $(6.18)$ & $(6.00)$ & $(6.29)$ \\
\hline \multirow[t]{2}{*}{ Disclosure index } & $-12.12^{* *}$ & $-9.08^{*}$ & $-13.22^{* *}$ & $-10.39^{*}$ & $-10.91^{* *}$ & $-8.98^{*}$ & $-12.41 * *$ & -8.16 \\
\hline & $(4.96)$ & $(4.83)$ & $(5.82)$ & $(5.64)$ & $(5.18)$ & $(5.18)$ & $(5.79)$ & $(5.49)$ \\
\hline \multirow[t]{2}{*}{ Banking crisis dummy } & 1.16 & 4.28 & 0.92 & 3.84 & 5.31 & 2.19 & 1.36 & 8.38 \\
\hline & $(7.50)$ & (8.22) & $(8.81)$ & $(9.61)$ & $(7.77)$ & $(8.72)$ & $(8.75)$ & $(9.34)$ \\
\hline \multicolumn{9}{|l|}{ Legal origin } \\
\hline \multirow[t]{2}{*}{ Anglo-Saxon } & & -8.10 & & -6.10 & & $-15.82^{*}$ & & -6.80 \\
\hline & & $(7.71)$ & & (9.02) & & $(8.46)$ & & $(8.74)$ \\
\hline \multirow[t]{2}{*}{ German } & & 13.41 & & $23.06^{*}$ & & 2.08 & & 20.71 \\
\hline & & (11.63) & & $(13.59)$ & & $(12.59)$ & & (13.19) \\
\hline \multirow[t]{2}{*}{ Scandinavian } & & 9.36 & & 13.85 & & 18.48 & & 5.33 \\
\hline & & $(14.77)$ & & $(17.24)$ & & $(15.56)$ & & $(16.78)$ \\
\hline \multirow[t]{2}{*}{ Socialist } & & $19.93^{*}$ & & $21.49^{*}$ & & 6.12 & & $30.60^{* * *}$ \\
\hline & & $(10.56)$ & & (12.38) & & (11.22) & & $(12.00)$ \\
\hline \multirow[t]{2}{*}{ Constant } & $63.33^{* * *}$ & $53.17^{* * *}$ & $65.32^{* * *}$ & $54.46^{* * *}$ & $49.27^{* * *}$ & $50.59^{* * *}$ & $71.37^{* * *}$ & $53.77^{* * *}$ \\
\hline & $(11.55)$ & (12.91) & $(13.56)$ & (15.09) & $(12.06)$ & (13.98) & $(13.48)$ & (14.65) \\
\hline $\mathbf{N}$ of observations & 63 & 63 & 63 & 63 & 63 & 63 & 63 & 63 \\
\hline Log Likelihood & -268.57 & -264.21 & -269.64 & -265.47 & -245.20 & -241.35 & -277.41 & -271.74 \\
\hline
\end{tabular}

***, ${ }^{* *}$ and $*$ indicate significance at the $1 \%, 5 \%$ and $10 \%$ level, respectively.

Standard errors in parentheses. 